\title{
Influence of the Small Sc and Zr Additions on the As-Cast Microstructure of Al-Mg-Si Alloys with Excess Silicon
}

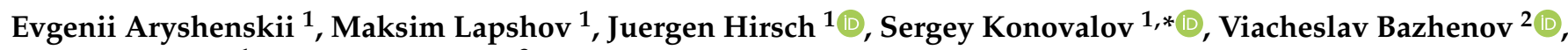 \\ Alexander Drits ${ }^{1}$ and Denis Zaitsev ${ }^{3}$ \\ 1 Department of Metals Technology and Aviation Materials, Samara National Research University, \\ Moskovskoye Shosse 34, 443086 Samara, Russia; ar-evgenii@yandex.ru (E.A.); \\ lapshov.m.syz@gmail.com (M.L.); juergen.hirsch@hydro.com (J.H.); Alexander.Drits@arconic.com (A.D.) \\ 2 Casting Department, National University of Science and Technology (MISIS), Leninskiy Prospekt 4, \\ 119049 Moscow, Russia; v.e.bagenov@gmail.com \\ 3 Laboratory of Metallophysical Research, All-Russian Scientific Research Institute of Aviation Materials, Radio \\ Street 17, 105005 Moscow, Russia; sale@isp.viam.ru \\ * Correspondence: ksv@ssau.ru; Tel.: +7-846-2674-640
}

check for updates

Citation: Aryshenskii, E.; Lapshov, M.; Hirsch, J.; Konovalov, S.; Bazhenov, V.; Drits, A.; Zaitsev, D. Influence of the Small Sc and $\mathrm{Zr}$ Additions on the As-Cast Microstructure of Al-Mg-Si Alloys with Excess Silicon. Metals 2021, 11, 1797. https://doi.org/10.3390/ met11111797

Academic Editor: Elisabetta Gariboldi

Received: 14 October 2021

Accepted: 5 November 2021

Published: 8 November 2021

Publisher's Note: MDPI stays neutral with regard to jurisdictional claims in published maps and institutional affiliations.

Copyright: (c) 2021 by the authors. Licensee MDPI, Basel, Switzerland. This article is an open access article distributed under the terms and conditions of the Creative Commons Attribution (CC BY) license (https:/ / creativecommons.org/licenses/by/ $4.0 /)$.

\begin{abstract}
This research is devoted to the study effects of complex alloying of Al-0.3 wt. \% Mg-1 wt. \% Si and Al-0.5 wt. \% Mg-1.3 wt. \% Si alloys by small additions of Sc and Zr on the microstructure in the as-cast condition. The effect of small additions of these elements on the microhardness, electrical conductivity, grain size and phase composition of the indicated alloy systems was studied. The methods of optical and electron microscopy were used for the study. Moreover, the phase composition was calculated using the Thermo-Calc software package. The study showed a strong effect of the chemical composition of investigated alloys on the size of the grains, which, with a certain combination of additives, can decrease several times. Grain refinement occurs both due to supercooling and formation of primary $\mathrm{Al}_{3} \mathrm{Sc}$ particles in the liquid phase. Alloys based on Al-0.5 wt. \% Mg-1.3 wt. \% Si are more prone to the formation of this phase since a lower concentration of Sc is required for it to occur. In addition, more silicon interacts with other elements. At the same time, Al-0.3 wt. \% Mg-1 wt. \% Si requires lower temperature for complete dissolution of $\mathrm{Mg}_{2} \mathrm{Si}$, which can contribute to more efficient heat treatment, which includes reducing the number of steps. TEM data show that during ingot cooling $(\mathrm{AlSi})_{3} \mathrm{ScZr}$ dispersoid precipitates. This dispersoid could precipitate as coherent and semi-coherent particles with $\mathrm{L}_{2}$ structure as well as needle-shaped particles. The precipitation of coherent and semi-coherent particles during cooling of the ingot indicates that they can be obtained during subsequent multistage heat treatment. In addition, in the $\mathrm{Al}_{0.5} \mathrm{Mg}_{1.3} \mathrm{Si}_{0.3} \mathrm{Sc}$ alloy, metastable $\beta^{\prime \prime}\left(\mathrm{Mg}_{5} \mathrm{Si}_{6}\right)$ are precipitated.
\end{abstract}

Keywords: aluminum alloys; phase composition; casting; Sc and Zr small addition; grain refinement; dispersoid

\section{Introduction}

Aluminum alloys are widely used in modern industry due to their combination of low density and high ductility [1-10]. Nowadays, aluminum alloys of the 6XXX series (Al-Mg-Si) are gaining popularity [11-18]. This series has an average strength that can be increased by heat treatment, namely by metastable $\beta^{\prime \prime}\left(\mathrm{Mg}_{5} \mathrm{Si}_{6}\right)$ particles coherent to the aluminum matrix.

Further improvement of the properties of this alloy series is possible due to small additions of Sc and Zr. These elements are poorly soluble in the aluminum matrix and form coherent strengthening $\mathrm{Al}_{3}(\mathrm{ScZr})$ nanoparticles [19-21]. In addition, these additives contribute to grain refinement during casting [19-21], and also contribute to the control of the recrystallization process [21] which also increases the mechanical properties. Alloying with zirconium and scandium is especially common for 5XXX group alloys, i.e., with a high 
content of magnesium [22,23], however, it is effectively used also in other aluminum alloy systems [24]. In recent years, active research on the use of these additives in 6XXX series alloys has been started [25-28]. In the future, it is possible to achieve a significant increase in strength due to the combined effect of grain refinement, and the simultaneous usage of strengthening particles $\mathrm{Al}_{3}(\mathrm{ScZr})$ and $\beta^{\prime \prime}\left(\mathrm{Mg}_{5} \mathrm{Si}_{6}\right)$. At the same time, $\mathrm{Sc}$ alloying of this group is a rather difficult task. The reason is that silicon addition changes the kinetics and chemical composition of scandium-containing dispersoids. As a result it provokes the appearance of an undesirable, $\mathrm{AlSc}_{2} \mathrm{Si}_{2}$ phase [25]. Because of this, some sources have noted a negative effect of scandium on the properties of the Al-Mg-Si alloys [25,29]. In order to avoid $\mathrm{AlSc}_{2} \mathrm{Si}_{2}$, it is necessary to carefully select the chemical composition (mainly by changing the amount of zirconium) and control the casting and heat treatment modes. In this case, due to joint scandium-zirconium alloying, it is possible to improve the properties of the 6XXX group alloys even if the ratio of the wt. fractions is $\mathrm{Mg} / \mathrm{Si}<1.73[25,30,31]$. In alloys of the $\mathrm{Al}-\mathrm{Mg}-\mathrm{Si}$ system with ratio $\mathrm{Mg} / \mathrm{Si}<1.73$, not all silicon combines with magnesium into the $\mathrm{Mg}_{2} \mathrm{Si}$ phase (or its metastable modifications such as $\beta^{\prime \prime}$ ) and there is an excess of it. It should be noted that, on the one hand, the increased silicon content enhances the properties in this group of alloys, due to the more evenly distributed and more finely dispersed strengthening particles $\beta^{\prime \prime}$ [17]. However, on the other hand, with the addition of scandium, excess silicon will increase the tendency to form $\mathrm{AlSc}_{2} \mathrm{Si}_{2}$. At the same time, the study of the processes occurring during casting and heat treatment of 6XXX group alloys with scandium-zirconium additives made it possible to avoid the undesirable phase and, in general, to improve the properties at a ratio $\mathrm{Mg} / \mathrm{Si}>1.73$ in AA6082 [26,30,32]. The possibility of further decreasing this ratio is promising since it will allow scandium and zirconium to be added to alloys such as 6016 where the excess of silicon is extremely large. However, it requires a thorough study on the effect of casting and thermomechanical treatment on the microstructure [26,30]. This article is devoted to the study of microstructure formation during casting of the 6XXX group alloys with a high silicon content and complex scandium and zirconium additives, especially in the range of element concentrations for which this problem has not yet be investigated.

\section{Experimental Methods}

\subsection{Material Preparation}

Two alloys with a low $\mathrm{Mg} / \mathrm{Si}$ ratio: 0.3 for $\mathrm{Al}_{0.3} \mathrm{Mg}_{1}$ Si and 0.38 for $\mathrm{Al}_{0.5} \mathrm{Mg}_{1.3}$ Si were chosen for the study. Both alloys were alloyed with small additions of $\mathrm{Zr}$ and $\mathrm{Sc}$ in the following combinations: $\mathrm{Al}_{-0.3} \mathrm{Mg}_{-1} \mathrm{Si}_{-} \mathrm{Sc}_{-} \mathrm{Zr}$ and $\mathrm{Al}_{-0.5} \mathrm{Mg}_{-1.3} \mathrm{Si}_{-} \mathrm{Sc}_{-} \mathrm{Z} \mathrm{Zr}$ alloys, where $\mathrm{X}$ $=0,0.1,0.2,0.3 \mathrm{wt}$. $\%$ and $Y=0,0.05,0.10,0.15 \mathrm{wt}$. \%. Its chemical composition are shown in Table 1.

Melting of alloys was carried out in a medium-frequency induction furnace using a graphite crucible, the melt weight was $4-5 \mathrm{~kg}$. The weight of the cast ingot was $3 \mathrm{~kg}$. The following materials were used as a charge for the alloy: aluminum (purity $99.8 \%$ ), magnesium (99.9\%), Al-2\%Sc master alloy, Al-12\%Si master alloy, and Al-5\%Zr master alloy. The casting temperature was $720-740{ }^{\circ} \mathrm{C}$. Before pouring the molten metal into the casting mold, it was refined with a carnallite flux introduced at the rate of $5 \mathrm{~g}$ per $1 \mathrm{~kg}$ of charge. After that, the metal was poured into a steel mold at a uniform pouring time of $40 \mathrm{~s}$. The obtained ingot size was $135 \mathrm{~mm} \times 30 \mathrm{~mm} \times 200 \mathrm{~mm}$ and its cooling speed was $2{ }^{\circ} \mathrm{C} / \mathrm{s}$. After solidification, the ingot was removed from the mold and cooled in water.

\subsection{Material Characterization}

Micro-hardness tests were carried out on a digital stationary hardness tester according to the micro-Vickers method on the HV-1000 model (test forces $0.2452 \mathrm{~N}$ ). In order to exclude the influence of grain boundaries and large intermetallic compounds, measurements were made in the grain center. Measurements of microhardness by indentation were carried out in accordance with GOST 9450-76 [33]. 
Table 1. Chemical composition of the investigated alloys.

\begin{tabular}{|c|c|c|c|c|c|c|c|c|c|c|c|}
\hline \multirow{2}{*}{$\begin{array}{c}\text { Sample } \\
\text { Number № } 1\end{array}$} & \multicolumn{5}{|c|}{ Chemical Composition } & \multirow{2}{*}{$\begin{array}{c}\text { Sample } \\
\text { Number № } 2\end{array}$} & \multicolumn{5}{|c|}{ Chemical Composition } \\
\hline & Al & $\mathrm{Mg}$ & Si & Sc & $\mathrm{Zr}$ & & Al & $\mathrm{Mg}$ & $\mathbf{S i}$ & $\mathrm{Sc}$ & $\mathrm{Zr}$ \\
\hline 1 & base & 0.3 & 1.0 & 0 & 0 & 1 & base & 0.5 & 1.3 & 0 & 0 \\
\hline 2 & base & 0.3 & 1.0 & 0 & 0.05 & 2 & base & 0.5 & 1.3 & 0 & 0.05 \\
\hline 3 & base & 0.3 & 1.0 & 0 & 0.1 & 3 & base & 0.5 & 1.3 & 0 & 0.1 \\
\hline 4 & base & 0.3 & 1.0 & 0 & 0.15 & 4 & base & 0.5 & 1.3 & 0 & 0.15 \\
\hline 5 & base & 0.3 & 1.0 & 0.1 & 0 & 5 & base & 0.5 & 1.3 & 0 & 0 \\
\hline 6 & base & 0.3 & 1.0 & 0.1 & 0.05 & 6 & base & 0.5 & 1.3 & 0.1 & 0 \\
\hline 7 & base & 0.3 & 1.0 & 0.1 & 0.1 & 7 & base & 0.5 & 1.3 & 0.1 & 0.05 \\
\hline 8 & base & 0.3 & 1.0 & 0.1 & 0.15 & 8 & base & 0.5 & 1.3 & 0.1 & 0.1 \\
\hline 9 & base & 0.3 & 1.0 & 0.2 & 0 & 9 & base & 0.5 & 1.3 & 0.1 & 0.15 \\
\hline 10 & base & 0.3 & 1.0 & 0.2 & 0.05 & 10 & base & 0.5 & 1.3 & 0.2 & 0.05 \\
\hline 11 & base & 0.3 & 1.0 & 0.2 & 0.1 & 11 & base & 0.5 & 1.3 & 0.2 & 0.1 \\
\hline 12 & base & 0.3 & 1.0 & 0.2 & 0.15 & 12 & base & 0.5 & 1.3 & 0.2 & 0.15 \\
\hline 13 & base & 0.3 & 1.0 & 0.3 & 0 & 13 & base & 0.5 & 1.3 & 0.3 & 0 \\
\hline 14 & base & 0.3 & 1.0 & 0.3 & 0.05 & 14 & base & 0.5 & 1.3 & 0.3 & 0.05 \\
\hline 15 & base & 0.3 & 1.0 & 0.3 & 0.1 & 15 & base & 0.5 & 1.3 & 0.3 & 0.1 \\
\hline 16 & base & 0.3 & 1.0 & 0.3 & 0.15 & 16 & base & 0.5 & 1.3 & 0.3 & 0.15 \\
\hline
\end{tabular}

The grain structure of the samples was examined using a Carl Zeiss Axiovert-40 MAT optical microscope (Carl Zeiss AG, Oberkochen, Germany). The preparation of microsections included cutting out samples, mechanical grinding, polishing, as well as electropolishing in a fluoroboric electrolyte of the following composition: boric acid-11 g, hydrofluoric acid- $30 \mathrm{~mL}$, distilled water-2200 $\mathrm{mL}$. For each sample, the mean grain size was measured by the linear intercept method.

Intermetallic particles were investigated using a JEOL 6390A SEM. The sample preparation technique consisted of mechanical grinding, polishing and electropolishing. Electropolishing was carried out at a temperature of $85-110^{\circ} \mathrm{C}$ and a voltage of $10-30 \mathrm{~V}$ in an electrolyte of the following composition: $500 \mathrm{~mL}$ of $\mathrm{H}_{3} \mathrm{PO}_{4} ; 300 \mathrm{~mL} \mathrm{H}_{2} \mathrm{SO}_{4} ; 50 \mathrm{~g} \mathrm{CrO}_{3}$; $50 \mathrm{~mL} \mathrm{H}_{2} \mathrm{O}$. Study of the chemical composition of structural components by energy dispersive spectroscopy using the X-Max 80T detector in the energy range 0-10 keV (the energy resolution of the detector is $122 \mathrm{eV}$ ).

For effective phase counting, the image was made with maximum contrast until the appearance of "noise" points. The ImageJ program (1.52 u, National Institutes of Health, Wayne Rasband (NIH), Bethesda, MD, USA) was used to process the image to the desired contrast of the aluminum matrix and secondary phases.

The study was carried out on the Tecnai G2 F20 S-TWIN TMP transmission electron microscope with a thermal-field cathode at accelerating voltage of $200 \mathrm{kV}$. The chemical composition of the fine dispersion participles was studied by energy-dispersive spectroscopy (EDS) method using the X-Max $80 \mathrm{~T}$ detector in the energy range $0-10 \mathrm{keV}$. The energy resolution of the detector is $122 \mathrm{eV}$.

The sample preparation for the study was carried out in the following sequence: cutting out samples with a diameter of $3 \mathrm{~mm}$ and a thickness of $0.3 \mathrm{~mm}$ on the Art's electric discharge machine, mechanical thinning on $\mathrm{SiC}$ paper from both sides, electrolytic polishing on a Tenupol-5 installation in a nitrogen-alcohol electrolyte. Polishing mode: $-38^{\circ} \mathrm{C}, 16 \mathrm{~V}$. 


\subsection{Phase Diagram Calculation}

The polythermal sections of phase diagrams was calculated using the Thermo-Calc 2016a software. Thermodynamic database TCAL4 (Thermo-Calc Software Al-based alloy database, Stockholm, Sweden, Version 4.0) was used [34].

\section{Results}

\subsection{Grain Refinement}

The results of the grain structure investigation showed very large dendritic grains, the sizes of which were several millimeters (Figure $1 \mathrm{a}$ ), in the $\mathrm{Al}_{0.3} \mathrm{Mg}_{1} \mathrm{Si}$ alloy without the addition of any transition elements. This is generally characteristic of low-alloyed alloys [35]. Upon the addition of Sc (Figure 1b) and Zr (Figure 1c), the size of the grain structure continues to decrease but not significantly. The scandium concentration is $0.6 \%$ which is required to achieve a hypereutectic composition and the formation of primary $\mathrm{Al}_{3} \mathrm{Sc}$ particle in the liquid [21]. Therefore, in $\mathrm{Al}_{0.3} \mathrm{Mg}_{1} \mathrm{Si}_{0.3} \mathrm{Sc}$ alloy grain refinement occurs due to supercooling at the boundaries of the nuclei and the liquid phase [36]. The concentration of zirconium $\mathrm{Al}_{0.3} \mathrm{Mg}_{1} \mathrm{Si}_{0.15} \mathrm{Zr}$ reaches a peretectic point of $0.11 \%$ [36]. However, significant grain refinement is not observed. It is explained by the fact, that according to [36] at the given concentration, the primary particles of $\mathrm{Al}_{3} \mathrm{Zr}$ only begin to form in the liquid and a significant grain-refinement effect is observed at a concentration of $0.2 \%$.The concentration of $0.3 \mathrm{Sc}$ and $0.15 \mathrm{Zr}$ is sufficient for the hypereutectic composition and the formation of primary $\mathrm{Al}_{3} \mathrm{Sc}$ particles in the liquid phase, which leads to a significant appearance of a fine-grained equiaxed structure during casting (Figure 1d).

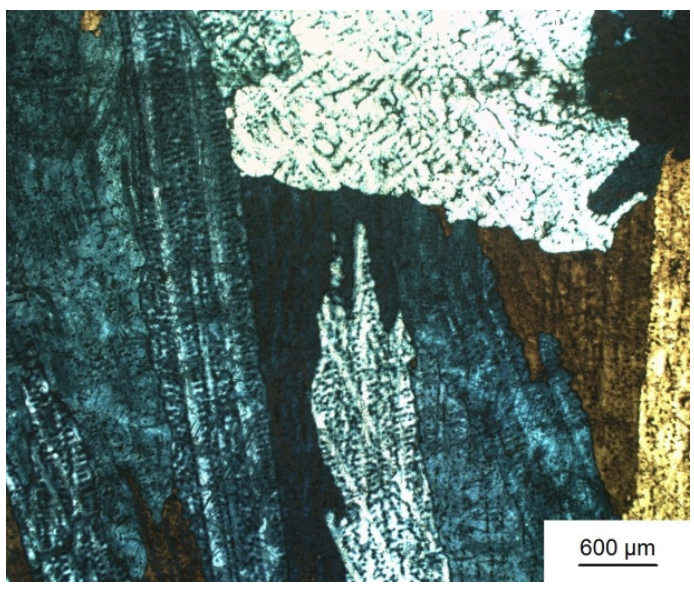

(a)

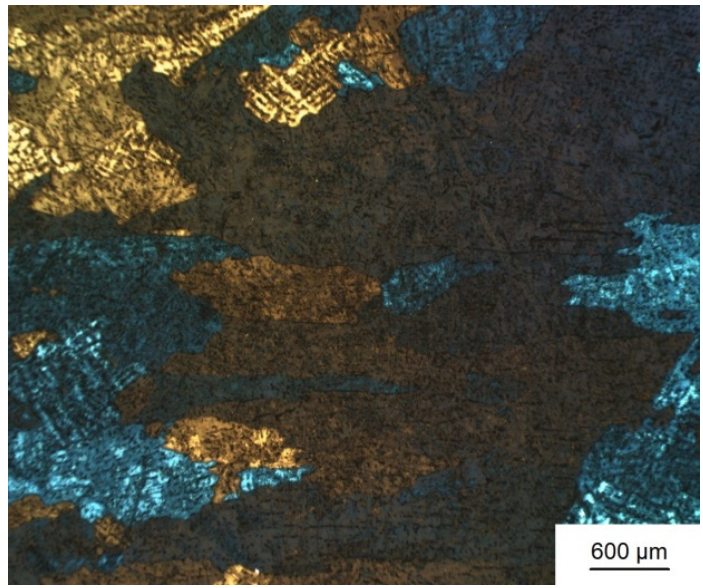

(c)

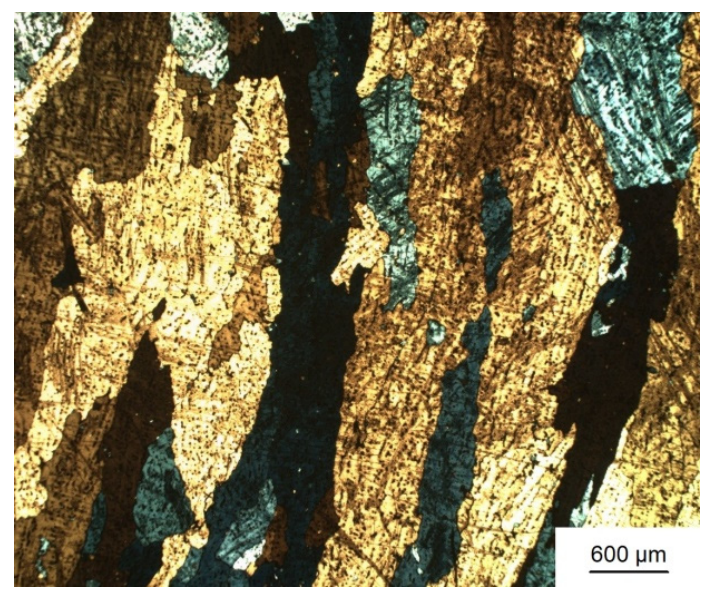

(b)

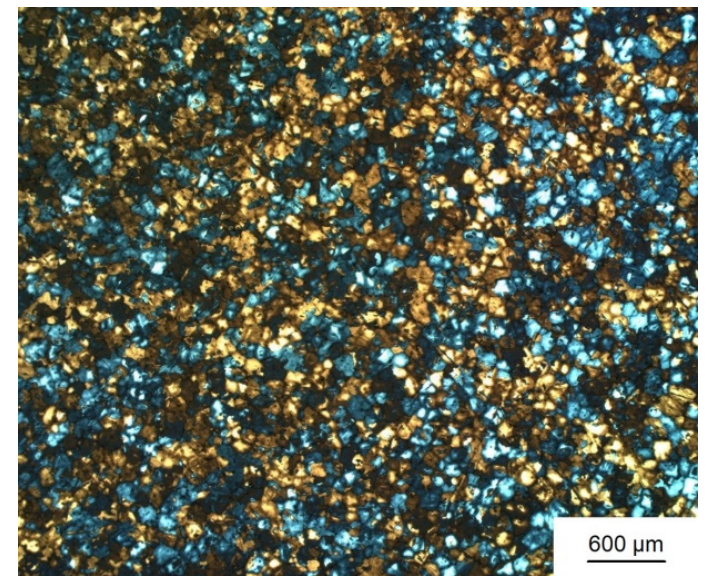

(d)

Figure 1. Grain structure after casting (a) $\mathrm{Al}_{0.3} \mathrm{Mg}_{1} \mathrm{Si}$, (b) $\mathrm{Al}_{0.3} \mathrm{Mg}_{1} \mathrm{Si}_{0.3} \mathrm{Sc}$, (c) $\mathrm{Al}_{0.3} \mathrm{Mg}_{1} \mathrm{Si}_{0.15} \mathrm{Zr}_{,}(\mathbf{d}) \mathrm{Al}_{0.3} \mathrm{Mg}_{1} \mathrm{Si}_{0.3} \mathrm{Sc}_{0.15} \mathrm{Zr}_{\text {. }}$ 
A dendritic structure is observed in the $\mathrm{Al}_{0.5} \mathrm{Mg}_{1.3} \mathrm{Si}$ alloy (Figure 2a), as well as in $\mathrm{Al}_{0.3} \mathrm{Mg}_{1} \mathrm{Si}$. However, the grain size in $\mathrm{Al}_{0.5} \mathrm{Mg}_{1.3} \mathrm{Si}$ is two times smaller. This effect is caused by an increase in the content of $\mathrm{Mg}$ and $\mathrm{Si}$, which also leads to supercooling between the nuclei and the liquid phase. Additions of scandium (Figure 2b) or zirconium (Figure 2c) alone only slightly affect the grain size. Their combined use leads to the appearance of fine equiaxed grains which, however, only partially replace the dendritic structure (Figure 2d). The decrease in alloying efficiency will be explained later.

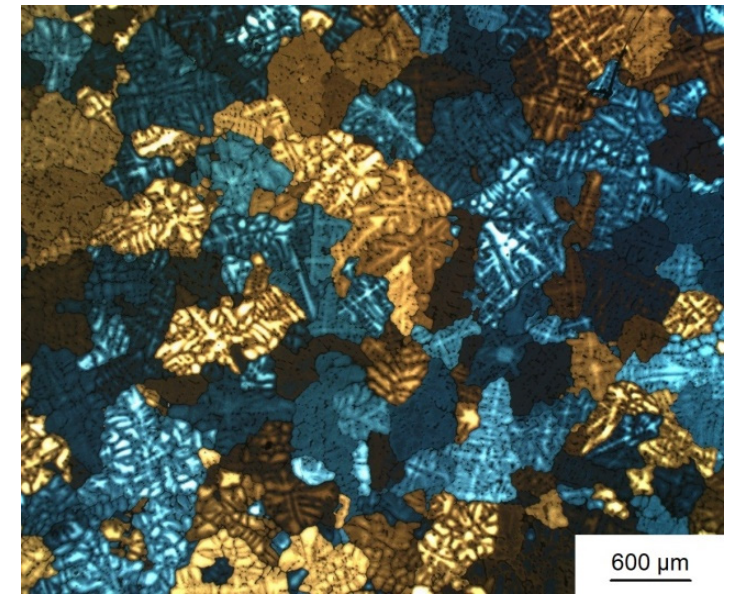

(a)

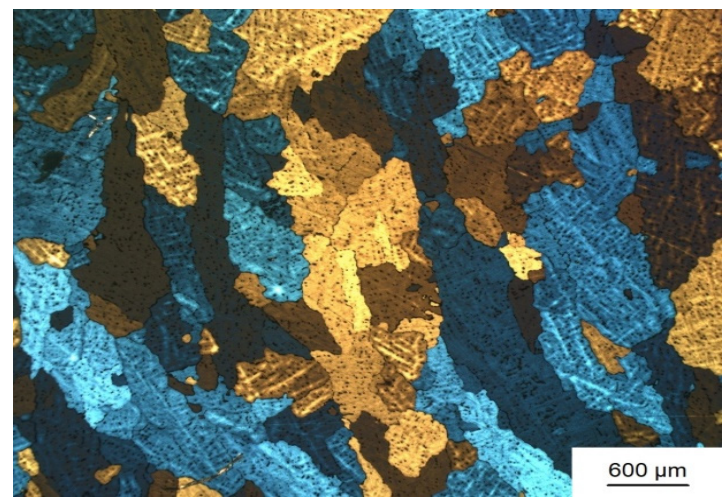

(c)

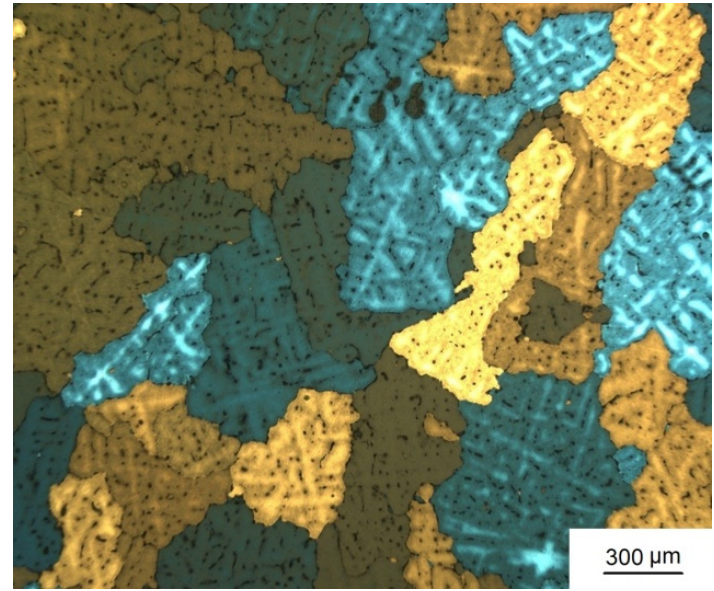

(b)

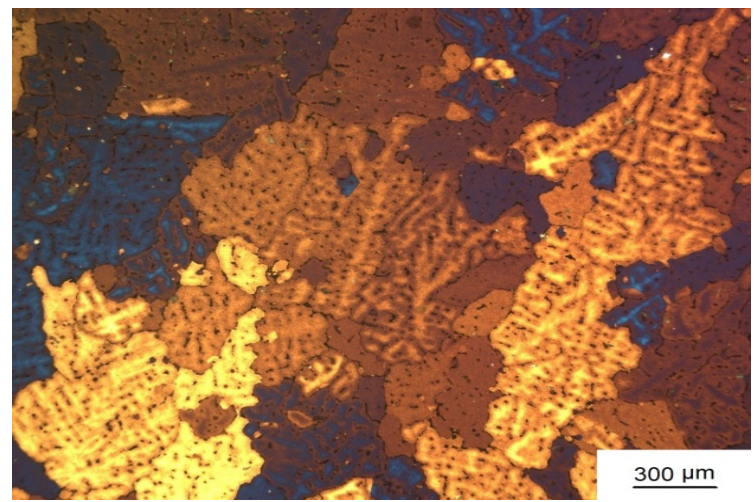

(d)

Figure 2. Grain structure after casting (a) $\mathrm{Al}_{0.5} \mathrm{Mg}_{1.3} \mathrm{Si}$ (b) $\mathrm{Al}_{0.5} \mathrm{Mg}_{1.3} \mathrm{Si}_{0.3} \mathrm{Sc}$, (c) $\mathrm{Al}_{0.5} \mathrm{Mg}_{1.3} \mathrm{Si}_{0.3} \mathrm{Zr}_{\text {, }}(\mathbf{d}) \mathrm{Al}_{0.5} \mathrm{Mg}_{1.3} \mathrm{Si}_{0.3} \mathrm{Sc}_{0.15} \mathrm{Zr}_{\text {. }}$

Thus, a gradual grain refinement occurs during complex alloying with small additions of zirconium and scandium. The decrease in the grain size is explained, first, by the fact that the growing content of scandium and zirconium causes supercooling between the liquid and the surface of the nuclei formed during solidification thereby facilitating the passing of the latter [36]. This also explains the fact that the grain in $\mathrm{Al}_{0.5} \mathrm{Mg}_{1.3} \mathrm{Si}$ (Figure 3a) is finer than in $\mathrm{Al}_{0.3} \mathrm{Mg}_{1} \mathrm{Si}$ (Figure $3 \mathrm{~b}$ ) after solidification, since the total number of alloying elements increases. With a further increase in the Sc and Zr contents, an almost 10-fold decrease in grain size occurs, mainly because the eutectic composition for Al-Sc-Zr system is reached [37]. As already mentioned, due to the high concentration of $\mathrm{Zr}$ and Sc in the $\mathrm{Al}_{0.5} \mathrm{Mg}_{1.3} \mathrm{Si}$ alloys, the grain refinement is more effective than in $\mathrm{Al}_{0.3} \mathrm{Mg}_{1} \mathrm{Si}$. An explanation of this fact will be given later. Note, however, that no appreciable refinement occurs with an increase in $\mathrm{Zr}$ or Sc alone. This is due to the fact that a scandium content of $0.6 \%$ is required for the hypereutectic composition and significant grain refinement. At the same time, an increase in $\mathrm{Zr}$ content to $0.15 \%$ reduces the scandium content which is necessary for the hypereutectic composition to $0.2 \%$. It should be noted that the amount of zirconium required for the overflow reaction of the zirconium content should be about 
$0.26 \%$. Therefore, it is not efficient for a significant refinement of the grain structure during casting in the concentration range studied here.

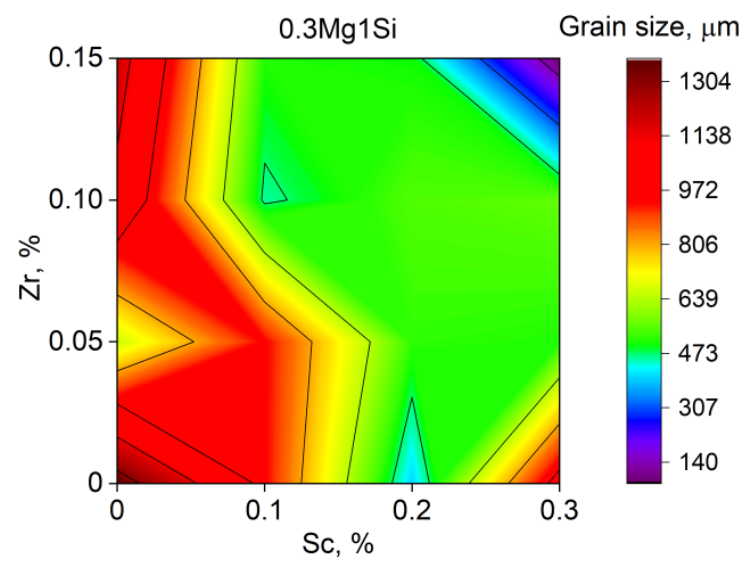

(a)

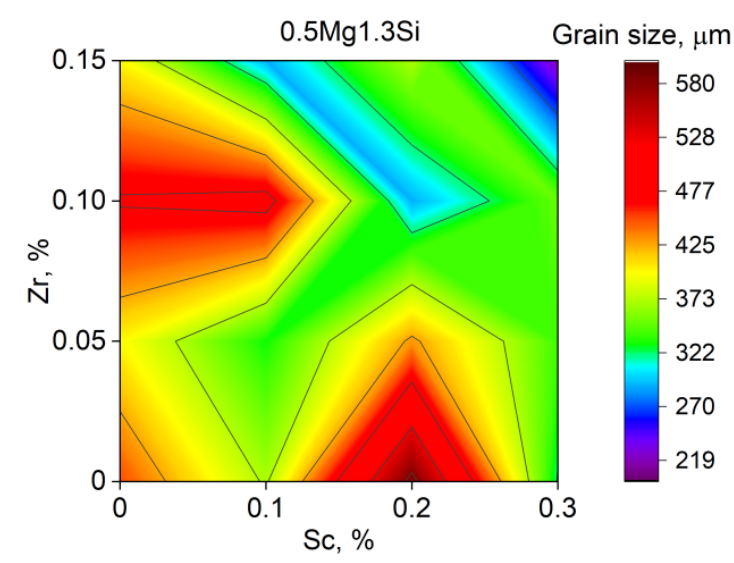

(b)

Figure 3. Grain size at complex alloying with small $\mathrm{Sc}$ and $\mathrm{Zr}$ additives (a) in alloys based on $\mathrm{Al}_{0.3} \mathrm{Mg}_{1} \mathrm{Si}_{\text {, }}(\mathbf{b})$ on $\mathrm{AL}_{0.5} \mathrm{Mg}_{1.3} \mathrm{Si}$.

\subsection{Microhardness Behavior}

The results of microhardness measurements are very interesting. It is generally higher (Figure 4a) in an alloy with a higher silicon content than in an alloy with a low silicon content (Figure $4 \mathrm{~b}$ ). This can be explained by the fact that alloy $\mathrm{Al}_{0.3} \mathrm{Mg}_{1} \mathrm{Si}$ contains more particles of the type (AlSi) ${ }_{3} \mathrm{ScZr}$ and / or $\mathrm{AlSc}_{2} \mathrm{Si}_{2}$ than $\mathrm{Al}_{0.5} \mathrm{Mg}_{1.3} \mathrm{Si}$. They can appear due to the fact that the cooling process during casting requires a certain time, which is sufficient for the precipitation of a certain amount of these particles from the supersaturated solid solution [26]. An increased ratio of magnesium and silicon will accelerate the precipitation of these particles from the supersaturated solid solution and thereby increase the microhardness. At the same time, an increase in the zirconium content will reduce the ability to form them upon cooling, since this element reduces the diffusion of scandium [19]. As for the $\mathrm{Al}_{0.5} \mathrm{Mg}_{1.3} \mathrm{Si}$ alloy (Figure $4 \mathrm{~b}$ ), it can be assumed that grain refinement, associated with an increase in the proportion of zirconium and scandium, will have a stronger effect than a decrease in the diffusion of the latter. As mentioned earlier, due to the larger amount of $\mathrm{Mg}$ and $\mathrm{Si}$, the refinement of the grain structure will be much stronger. Therefore, the length of grain boundaries is longer. The latter, in turn, serve as an additional source in the formation of secondary metastable particles, contributing to an increase in their number [38]. Note that the effect of the grain structure size can be excluded, since this indicator begins to exert a significant effect on the microhardness when reaching submicron sizes. Even in alloys with the finest grains its size is several microns.

\subsection{Phase Diagram Calculation Result}

Figure 5a,b shows polythermal sections of the systems Al-0.3\%Mg-1\%Si-0.15\%Zr$(0-0.4) \%$ Sc (wt. \%) and Al-0.5\%Mg-1.3\%Si-0.15\%Zr-(0-0.4)\%Sc. Note that alloys with a combined content of scandium and zirconium seem to be the most promising. Firstly, they allow to refine the grain structure which will positively affect the mechanical properties and, secondly, slow down the diffusion of scandium and foster the formation of metastable nanoparticles (AlSi) ${ }_{3} \mathrm{ScZr}$ coherent to aluminum matrix, instead of harmful $\mathrm{AlSc}_{2} \mathrm{Si}_{2}$. Therefore, polythermal sections with the highest zirconium content are considered. On the whole, phase transformations in both groups of alloys (with different $\mathrm{Mg} / \mathrm{Si}$ ratios) have common laws. Slightly below $700{ }^{\circ} \mathrm{C}$, primary $\mathrm{Al}_{3} \mathrm{Zr}$ particles begin to precipitate from the liquid. Three phases $\mathrm{L}+\mathrm{Al}_{3} \mathrm{Zr}+(\mathrm{Al})$ are simultaneously present in a narrow range between 653-650 ${ }^{\circ} \mathrm{C}$ in $\mathrm{Al}_{0.3} \mathrm{Mg}_{1} \mathrm{Si}$ (Figure 5a) and $650-647{ }^{\circ} \mathrm{C}$ in $\mathrm{Al}_{0.5} \mathrm{Mg}_{1.3} \mathrm{Si}$ (Figure 6b). After that, $\mathrm{Al}_{3} \mathrm{Zr}$ dissolves and the $\mathrm{ZrSi}$ phase appears instead. With Sc content of up to $0.23 \%$ 
in $\mathrm{Al}_{0.3} \mathrm{Mg}_{1} \mathrm{Si}$ (Figure 5a) and up to $0.26 \%$ in $\mathrm{Al}_{0.5} \mathrm{Mg}_{1.3} \mathrm{Si}$ (Figure $5 \mathrm{~b}$ ), the $\mathrm{ZrSi}$ phase is transformed into $\mathrm{Zr}_{2} \mathrm{Si}$. At zero scandium content, upon reaching a temperature of $601{ }^{\circ} \mathrm{C}$ in $\mathrm{Al}_{0.3} \mathrm{Mg}_{1} \mathrm{Si}$ (Figure 5a) and $578{ }^{\circ} \mathrm{C}$ in $\mathrm{Al}_{0.5} \mathrm{Mg}_{1.3} \mathrm{Si}$ (Figure $5 \mathrm{~b}$ ), the metal finally solidifies. After that an aluminum solid solution and the $\mathrm{ZrSi}_{2}$ phase can be observed in the metal. With an increased concentration of scandium, the solidus temperature gradually decreases up to $0.14 \%$ and $0.07 \%$ of $\mathrm{Sc}$ for $\mathrm{Al}_{0.3} \mathrm{Mg}_{1} \mathrm{Si}$ and $\mathrm{Al}_{0.5} \mathrm{Mg}_{1.3} \mathrm{Si}$ alloys respectively and at higher concentration of $\mathrm{Sc}$ the solidus temperatures is slightly increased. When the Sc concentration reaches $0.21 \%$ in $\mathrm{Al}_{0.3} \mathrm{Mg}_{1} \mathrm{Si}$ (Figure 5a) and $0.25 \% \mathrm{Al}_{0.5} \mathrm{Mg}_{1.3} \mathrm{Si}$ (Figure 5b), $\mathrm{L}+(\mathrm{Al})+\mathrm{ZrSi}_{2}$ first transforms into $\mathrm{L}+(\mathrm{Al})+\mathrm{ZrSi}_{2}+\mathrm{Al}_{3} \mathrm{Sc}$ and then finally is solidified as $(\mathrm{Al})+\mathrm{ZrSi}_{2}+\mathrm{Al}_{3} \mathrm{Sc}$. When scandium reaches $0.24 \%$ in the $\mathrm{Al}_{0.3} \mathrm{Mg}_{1} \mathrm{Si}$ alloys (Figure 6a) and $0.27 \%$ in $\mathrm{Al}_{0.5} \mathrm{Mg}_{1.3} \mathrm{Si}$ (Figure $6 \mathrm{~b}$ ), solidification occurs according to the following scheme: $\mathrm{L}+(\mathrm{Al})+\mathrm{ZrSi}_{2} \rightarrow \mathrm{L}+(\mathrm{Al})+\mathrm{ZrSi}_{2}+\mathrm{Al}_{3} \mathrm{Sc} \rightarrow \mathrm{L}+(\mathrm{Al})+\mathrm{ZrSi}_{2}+\mathrm{SiSc} \rightarrow(\mathrm{Al})+$ $\mathrm{ZrSi}_{2}+\mathrm{Al}_{3} \mathrm{Sc}$. Upon reaching Sc $0.24 \%$ and $0.28 \%$ in the alloys $\mathrm{Al}_{0.3} \mathrm{Mg}_{1} \mathrm{Si}$ (Figure $5 \mathrm{a}$ ) and $\mathrm{Al}_{0.5} \mathrm{Mg}_{1.3} \mathrm{Si}$ (Figure $5 \mathrm{~b}$ ), solidification occurs along an even more complicated path: $\mathrm{L}+$ $(\mathrm{Al})+\mathrm{ZrSi} \rightarrow \mathrm{L}+(\mathrm{Al})+\mathrm{ZrSi}+\mathrm{Al}_{3} \mathrm{Sc} \rightarrow \mathrm{L}+(\mathrm{Al})+\mathrm{ZrSi}_{2}+\mathrm{Al}_{3} \mathrm{Sc} \rightarrow \mathrm{L}+(\mathrm{Al})+\mathrm{ZrSi}_{2}+\mathrm{SiSc}$ $\rightarrow(\mathrm{Al})+\mathrm{ZrSi}_{2}+\mathrm{SiSc}$. In addition, in a short interval between $0.23 \div 0.24 \%$ for $\mathrm{Al}_{0.3} \mathrm{Mg}_{1} \mathrm{Si}$ and $0.27 \div 0.28 \%$, solidification occurs according to the following scheme: $\mathrm{L}+(\mathrm{Al})+\mathrm{ZrSi}$ $\rightarrow \mathrm{L}+(\mathrm{Al})+\mathrm{ZrSi}_{2}+\mathrm{Al}_{3} \mathrm{Sc} \rightarrow \mathrm{L}+(\mathrm{Al})+\mathrm{ZrSi}_{2}+\mathrm{SiSc} \rightarrow(\mathrm{Al})+\mathrm{ZrSi}_{2}+\mathrm{SiSc}$

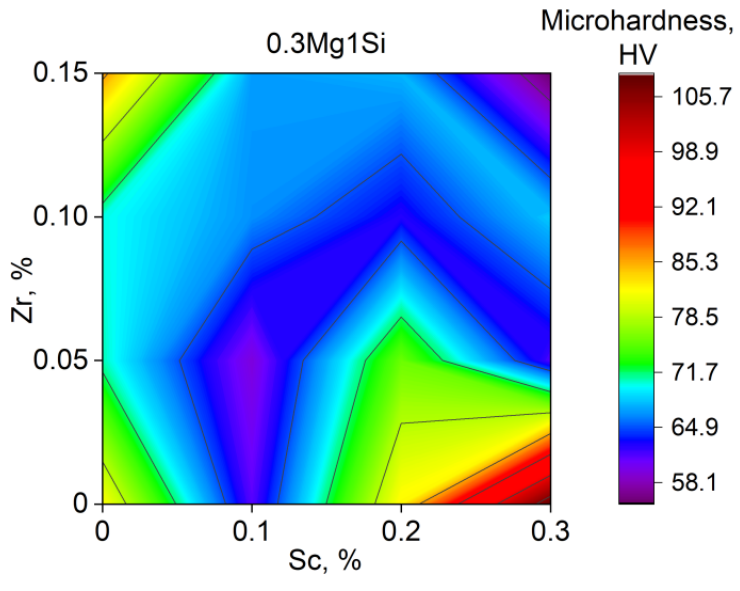

(a)

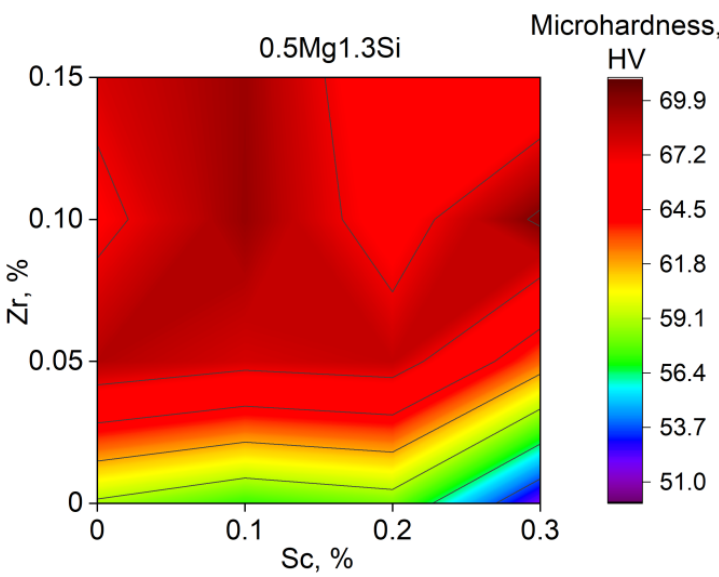

(b)

Figure 4. Microhardness with complex alloying with small additives $\mathrm{Sc}$ and $\mathrm{Zr}$ (a) in alloys based on $\mathrm{Al}_{0.3} \mathrm{Mg}_{1} \mathrm{Si}_{\text {, }}$ (b) on $\mathrm{Al}_{0.5} \mathrm{Mg}_{1.3} \mathrm{Si}$.

It should be noted that the appearance of primary particles in the liquid phase will facilitate grain refinement but not all of them will be equally effective. Primary $\mathrm{Al}_{3} \mathrm{Zr}$, and especially $\mathrm{Al}_{3} \mathrm{Sc}$, are effective inoculators due to the good correspondence between them and the aluminum matrix. There is no such information about $\mathrm{ZrSi}_{2}$ and $\mathrm{SiSc}$ particles. However, it can be assumed that their effectiveness is rather low.

Note that in the $\mathrm{Al}_{0.3} \mathrm{Mg}_{1} \mathrm{Si}_{0.3} \mathrm{Sc}_{0.15} \mathrm{Zr}$ alloy the combined grain refinement effect of zirconium and scandium does not differ from that observed in pure aluminum and alloys with a high magnesium content [37]. However, in the $\mathrm{Al}_{0.5} \mathrm{Mg}_{1.3} \mathrm{Si}_{0.3} \mathrm{Sc}_{0.15} \mathrm{Zr}$ alloy at concentrations sufficient to obtain a fine grain structure in pure aluminum and alloys with high magnesium content, a large number of dendritic grains are still observed. A first explanation for this is that $\mathrm{Al}_{3} \mathrm{Sc}$ and $\mathrm{Al}_{3} \mathrm{Zr}$ particles are not present at all stages of solidification. They will have a slightly weaker effect than in high-magnesium alloys. It should also be noted that $\mathrm{Al}_{3} \mathrm{Sc}$ particles, which contribute to efficient grain refinement, act even more efficiently in $\mathrm{Al}_{0.3} \mathrm{Mg}_{1} \mathrm{Si}$ alloys because their formation requires a lower scandium content than in $\mathrm{Al}_{0.5} \mathrm{Mg}_{1.3} \mathrm{Si}$. This explains the fact that the grain is larger in this group of alloys with a low content of $\mathrm{Zr}$ and $\mathrm{Sc}$ than in $\mathrm{Al}_{0.5} \mathrm{Mg}_{1.3} \mathrm{Si}$ with a similar content of these elements. However, the grain in $\mathrm{Al}_{0.3} \mathrm{Mg} 1 \mathrm{Si}$ is refined better with an increase in their concentration. At a low concentration of Sc and $\mathrm{Zr}$, the reason for the finer grain in the 
case of $\mathrm{Al}_{0.5} \mathrm{Mg}_{1.3} \mathrm{Si}$ is the aforementioned supercooling at the interface between the nuclei and the liquid phase (arising from the dissolved $\mathrm{Mg}$ and $\mathrm{Si}$ ). However, due to the lower Sc concentration required for the formation of $\mathrm{Al}_{3} \mathrm{Sc}$ particles during metal solidification, the refinement of the grain structure at high scandium concentrations is more efficient in $\mathrm{Al}_{0.3} \mathrm{Mg}_{1} \mathrm{Si}$.

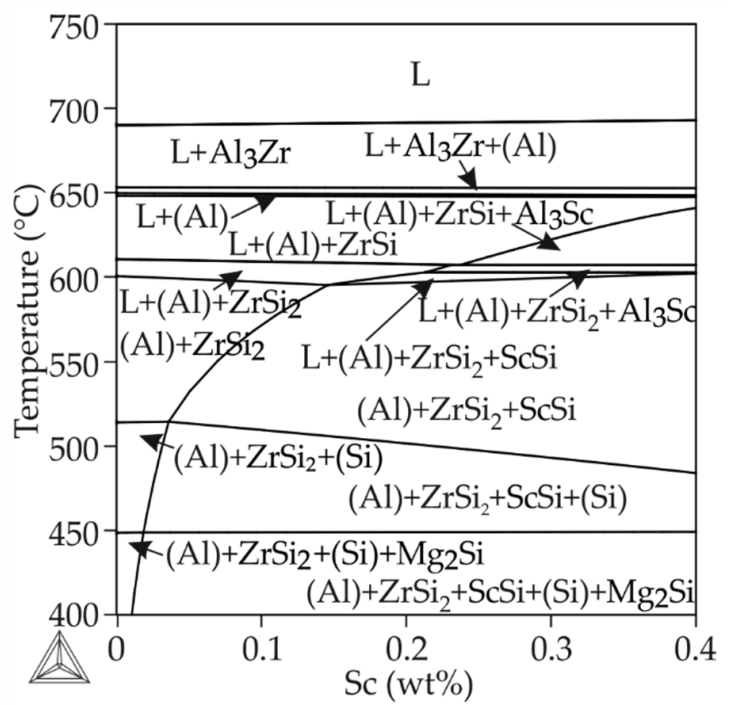

(a)

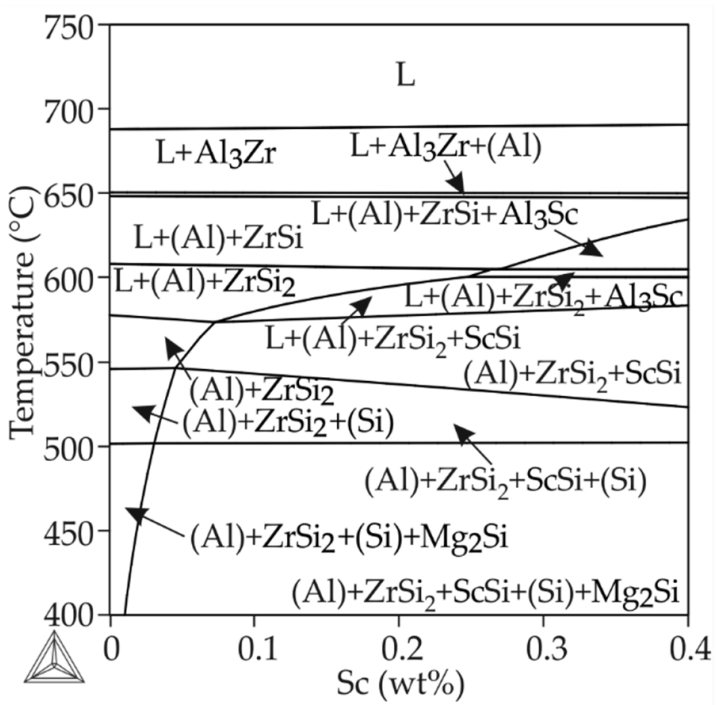

(b)

Figure 5. Polythermal sections (a) Al-0.3\%Mg-1\%Si-0.15\%Zr-(0-0.4)\% Sc (wt. \%) and (b) Al-0.5\%Mg- $1.3 \% \mathrm{Si}-0.15 \% \mathrm{Zr}-(0-$ $0.4) \% \mathrm{Sc}$ (wt. \%) of the Al-Mg-Si-Zr-Sc phase diagram calculated using Thermo-Calc software.

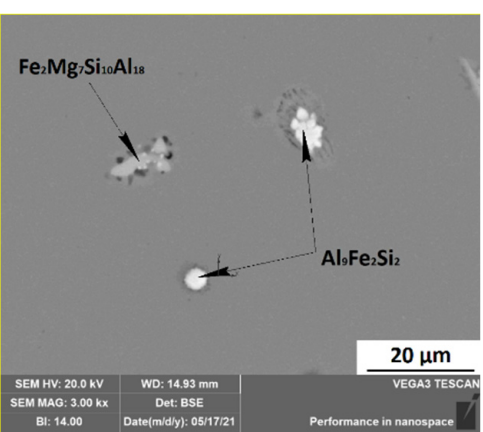

(a)

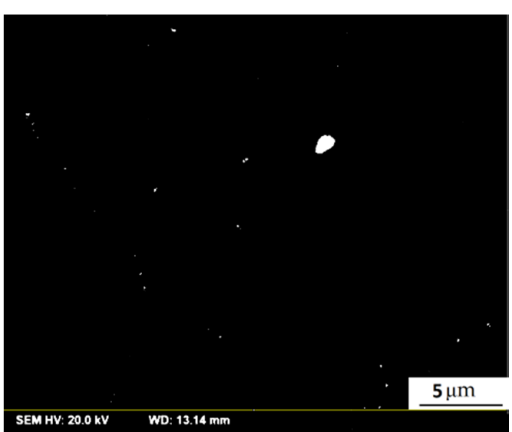

(b)

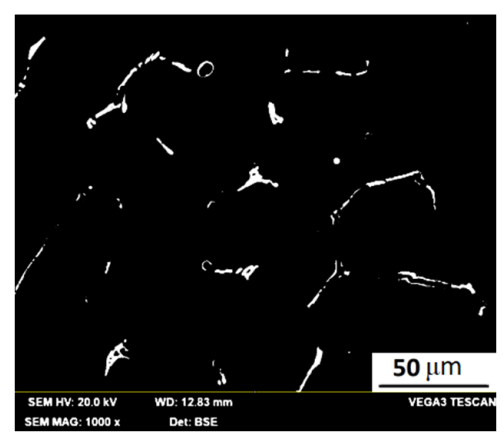

(c)

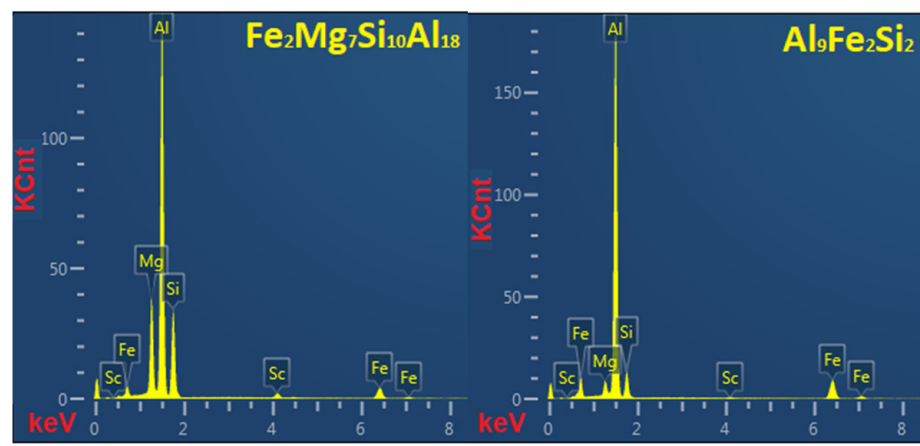

(d)

Figure 6. $\mathrm{Al}_{0.3} \mathrm{Mg}_{1} \mathrm{Si}_{0.3} \mathrm{Sc}$ main types of intermetallic compounds (a); small dispersoids (b); large particles (c); result of the energy-dispersive spectroscopy (EDS) investigation of chemical composition of the intermetallic compounds (d).

After solidification in both types of alloy, a similar chain of phase transformations is observed. At a low concentration of scandium, the following phase transformations will occur: $(\mathrm{Al})+\mathrm{ZrSi}_{2} \rightarrow(\mathrm{Al})+\mathrm{ZrSi}_{2}+(\mathrm{Si}) \rightarrow(\mathrm{Al})+\mathrm{ZrSi}_{2}+(\mathrm{Si})+\mathrm{Mg}_{2} \mathrm{Si}$. At a higher 
concentration of scandium, the following transformations will be observed: $(\mathrm{Al})+\mathrm{ZrSi}_{2}$ $+\mathrm{SiSc},(\mathrm{Al})+\mathrm{ZrSi}_{2}+\mathrm{SiSc}+(\mathrm{Si}) ;(\mathrm{Al})+\mathrm{ZrSi}_{2}+\mathrm{SiSc}+(\mathrm{Si})+\mathrm{Mg}_{2} \mathrm{Si}$. It may seem that the $\mathrm{Al}_{0.5} \mathrm{Mg}_{1.3} \mathrm{Si}$ system is more promising from the point of view of further use, since it has a larger $\mathrm{Mg} / \mathrm{Si}$ relationship than $\mathrm{Al}_{0.3} \mathrm{Mg}_{1} \mathrm{Si}$, which decreases the risk of the appearance of harmful particles of the $\mathrm{AlSc}_{2} \mathrm{Si}_{2}$-type. However, a lower dissolution temperature of $\mathrm{Mg}_{2} \mathrm{Si}$ particles in $\mathrm{Al}_{0.3} \mathrm{Mg}_{1} \mathrm{Si}$ alloys allows one to avoid additional heat treatment. To date, multistage heat treatment has been required to obtain two hardening phases ( $\mathrm{AlSi})_{3} \mathrm{ZrSc}$ and $\beta^{\prime \prime}\left(\mathrm{Mg}_{5} \mathrm{Si}_{6}\right)$ [26]. It consists in homogenization in order to maximize dissolution of $\mathrm{Sc}, \mathrm{Mg}$, Si and $\mathrm{Zr}$ into a supersaturated solid solution which includes eliminating large non-equilibrium particles. Three-stage annealing is applied after homogenization: The first step is the formation of $(\mathrm{AlSi})_{3} \mathrm{Sc}$ particles. Then $(\mathrm{AlSi})_{3} \mathrm{ScZr}$ particles are formed on their basis. The third stage consists of the dissolution of phases close to $\mathrm{Mg}_{2} \mathrm{Si}$, which at the fourth stage can be isolated in the form of a strengthening $\beta^{\prime \prime}\left(\mathrm{Mg}_{5} \mathrm{Si}_{6}\right)$ phase. However, at a low temperature of $\mathrm{Mg}_{2} \mathrm{Si}$ solubility, the fourth stage of annealing can be avoided, since all the necessary processes will occur at the third stage. Note that, according to the calculations performed in the current Thermo-Calc version, only equilibrium primary particles $\mathrm{Al}_{3} \mathrm{Zr}$ are present in the alloys studied. The appearance of $\mathrm{Al}_{3} \mathrm{Zr}$ as solid state equilibrium particle which has D023-structure was not predicted by this calculation. This, however, does not exclude the emerging of metastable particles which have $\mathrm{L}_{2}$ structure and composition close to $(\mathrm{AlSi})_{3} \mathrm{Zr}$.

\subsection{Investigation of the Intermetallic Participles by Scanning Electron Microscopy (SEM) Method}

The $\mathrm{Al}_{0.3} \mathrm{Mg}_{1} \mathrm{Si}_{0.33} \mathrm{Sc}$ alloy contains two types of particle; the first one can be described as being like $\mathrm{Al}_{3} \mathrm{Fe}_{2} \mathrm{Si}_{2}$. The second can be interpreted as being like quaternary $\pi$ phase $\mathrm{Fe}_{2} \mathrm{Mg}_{7} \mathrm{Si}_{10} \mathrm{Al}_{18}$ [39] which in this alloy can form due to there being no equilibrium solidification. Primary intermetallic compounds have both close to round (smaller) and needle-like shapes. Their average size is 12.4 microns. This alloy has an increased amount of fine particles which, among other things, explains its high microhardness (Figure 4a). Considering that no traces of scandium were found in large intermetallic particles with a fraction of its content in the solid solution of only $0.11 \%$, it can be assumed with a high degree of probability that it is in the form of fine particles, the fraction of which is $0.14 \%$. It should be noted that there is a high proportion of magnesium in the supersaturated solid solution. Therefore, it is insufficient for the formation of large intermetallic particles of the $\mathrm{Mg}_{2} \mathrm{Si}$ type. This chemical composition, as predicted in [25], is extremely unfavorable for the production of strengthening $\mathrm{Al}_{3} \mathrm{Sc}$ particles, since scandium actively interacts with silicon already during cooling after casting. In this case, $\mathrm{Mg}$ is used rather rarely. This means, firstly, the need for a prolonged homogenization (completed by quenching) to dissolve excess Sc and $\mathrm{Si}$ at high temperatures. In addition, with a high degree of probability the subsequent heat treatment and aging at $300{ }^{\circ} \mathrm{C}$ will not be accompanied by the precipitation of $\mathrm{Mg}_{2} \mathrm{Si}$-type particles. As a result, silicon will interact only with scandium, which will favor the predominant growth of unwanted $\mathrm{AlSc}_{2} \mathrm{Si}_{2}$ particles.

Figure 7 shows the results of electron microscopy for the alloy $\mathrm{Al}_{0.3} \mathrm{Mg}_{1} \mathrm{Si}_{0.3} \mathrm{Sc}_{0.15} \mathrm{Zr}$. It contains a number of large primary intermetallic such as $\mathrm{Al}_{9} \mathrm{Fe}_{2} \mathrm{Si}_{2},(\mathrm{Al}, \mathrm{Si})_{3} \mathrm{Sc}, \mathrm{Al}_{3} \mathrm{Sc}_{0.6} \mathrm{Zr}_{0.4}$ with an average size of 11.6 microns. It also contains particles with a composition close to quaternary $\pi$ phase $\mathrm{Fe}_{2} \mathrm{Mg}_{7} \mathrm{Si}_{10} \mathrm{Al}_{18}$. In this alloy, a fairly large amount of $\mathrm{Si}$ and $\mathrm{Sc}$ is in solid solution. This suggests that, for a given chemical composition, $\mathrm{Si}$ and $\mathrm{Sc}$ do not interact so intensely with each other. The presence of particles of both the $(\mathrm{Al}, \mathrm{Si})_{3} \mathrm{Sc}$ and $\mathrm{Al}_{3} \mathrm{Sc}_{0.6} \mathrm{Zr}_{0.4}$ types indicates that $\mathrm{Sc}$, upon further heat treatment, will react both with silicon, forming $\mathrm{AlSc}_{2} \mathrm{Si}_{2}$ particles, and with zirconium, forming $\mathrm{Al}_{3} \mathrm{Sc}_{0.6} \mathrm{Zr}_{0.4}$ particles. In this case magnesium also "absorbs" part of the silicon, contributing to the formation of $\mathrm{Mg}_{2} \mathrm{Si}$-type particles. Taking into account the results of Thermo-Calc calculations (Figure 5a), it can also be assumed that various $\mathrm{Zr}$ and $\mathrm{Si}$ compounds will occur during heat treatment. Thus, this alloy seems to be very promising for further study, since excessive silicon will interact both with magnesium and zirconium, as well as various impurities. With proper heat treatment, 
this will allow the required amount of $\mathrm{Al}_{3} \mathrm{ScZr}$ particles which have a $\mathrm{L}_{12}$ structure to be obtained.

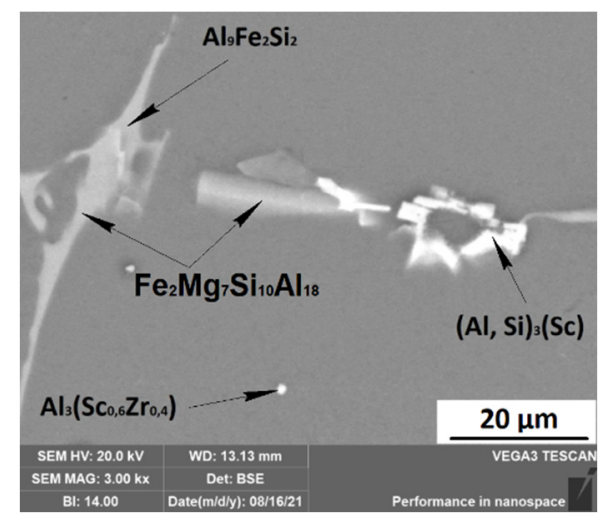

(a)

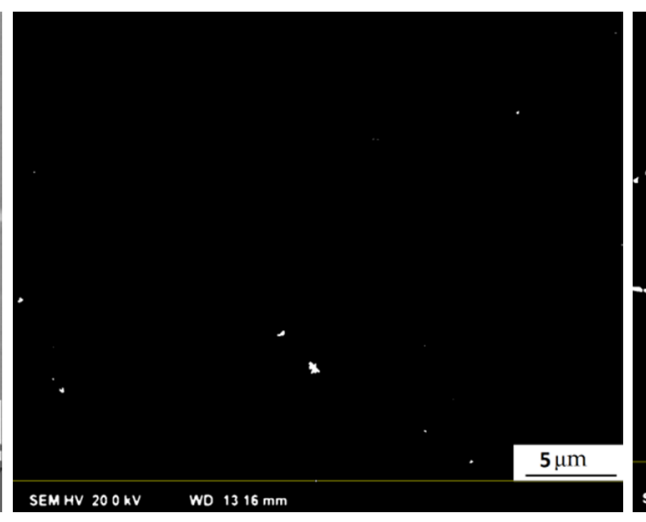

(b)

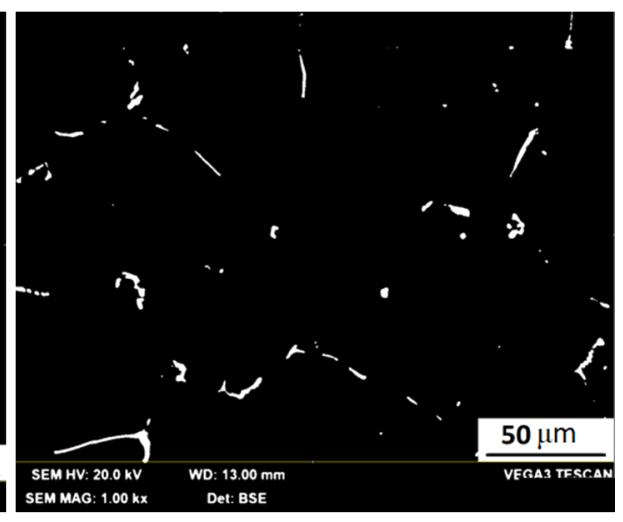

(c)

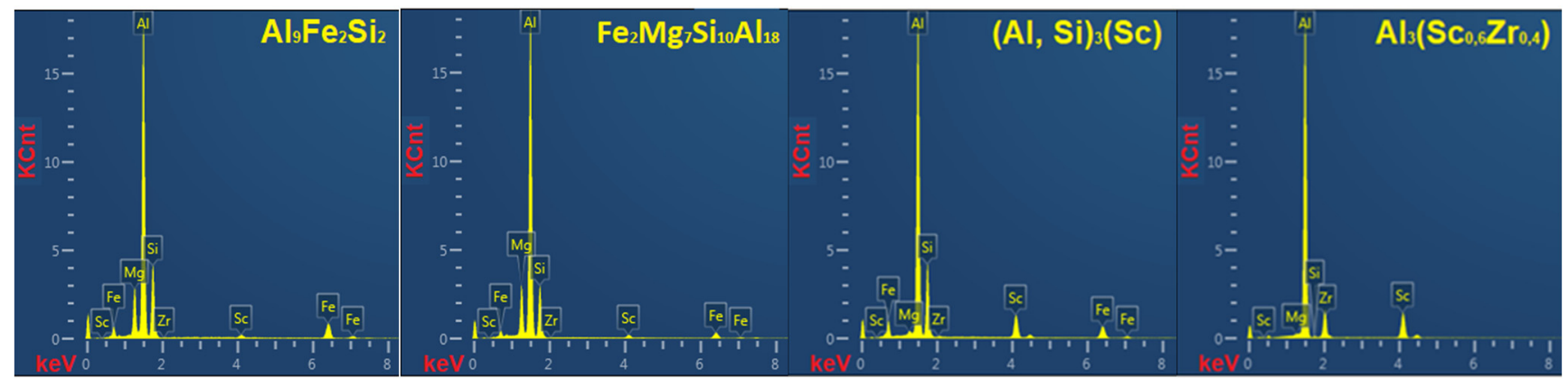

(d)

Figure 7. $\mathrm{Al}_{0.3} \mathrm{Mg}_{1} \mathrm{Si}_{0.3} \mathrm{Sc}_{0.15} \mathrm{Zr}$ main types of intermetallic compounds (a); small dispersoids (b); large particles (c); result of the EDS investigation of chemical composition of the intermetallic compounds (d).

The $\mathrm{Al}_{0.5} \mathrm{Mg}_{1.3} \mathrm{Si}_{0.3} \mathrm{Sc}$ alloy contains the main types of large primary non-equilibrium intermetallic compounds $\mathrm{A}_{19} \mathrm{Fe}_{2} \mathrm{Si}_{2}, \mathrm{Fe}_{2} \mathrm{Mg}_{7} \mathrm{Si}_{10} \mathrm{Al}_{18}$, and ( $\left.\mathrm{Al}, \mathrm{Si}\right)_{3} \mathrm{Sc}$. Their average size is 10.6 microns. In this case, there are spherical and needle-shaped particles, as well as large elongated eutectic particles arising along the boundaries of dendritic grains. Besides, there are many dispersoids in this alloy occupying $0.2 \%$ of the cross-sectional area, but with a rather large size.

In the $\mathrm{Al}_{0.5} \mathrm{Mg}_{1.3} \mathrm{Si}_{0.3} \mathrm{Sc}_{0.15} \mathrm{Zr}$ alloy, large intermetallic compounds are represented by $\mathrm{Fe}_{2} \mathrm{Mg}_{7} \mathrm{Si}_{10} \mathrm{Al}_{18}$ and $(\mathrm{Al}, \mathrm{Si})_{3}(\mathrm{Sc})$ particles with an average diameter of 12.8 microns. There are not so many dispersoids in the alloy, however, they have a size of about $30 \mathrm{~nm}$. Smaller dispersoids with an average size of 20-15 nm were detected using transmission microscopy. Considering also the fact that zirconium can practically not be observed in a supersaturated solid solution and in large intermetallic particles, it can be assumed that the main type of fine particles will be $\mathrm{Al}_{3} \mathrm{ScZr}$. Moreover, in this alloy $\mathrm{Si}$ reacts sufficiently with magnesium which makes it very promising for further research.

The results of electron microscopy are presented in:

- $\quad$ Table 2 (data on the size and quantity of fine particles);

- $\quad$ Table 3 (data on the size and quantity of large intermetallic particles);

- $\quad$ Table 4 (chemical composition of the main intermetallic particles) and Figures 6-9. 


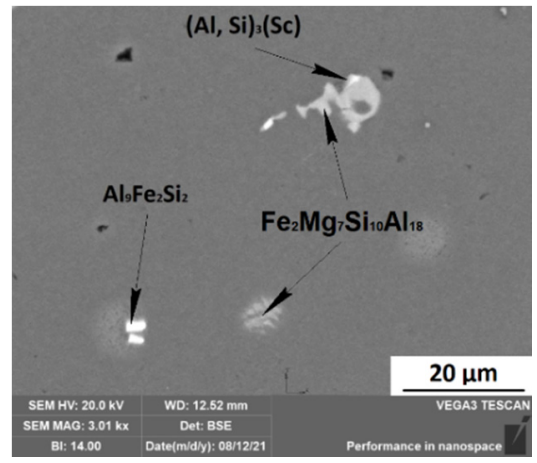

(a)

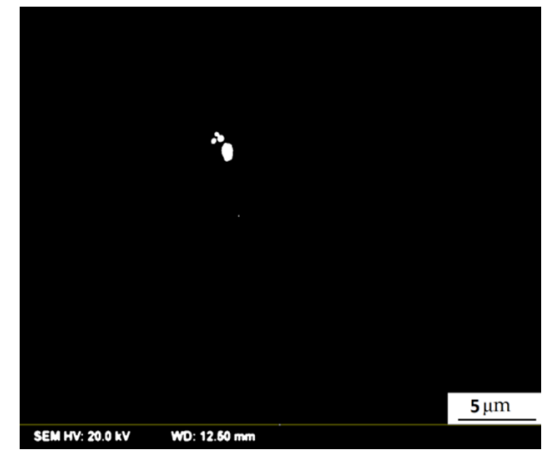

(b)

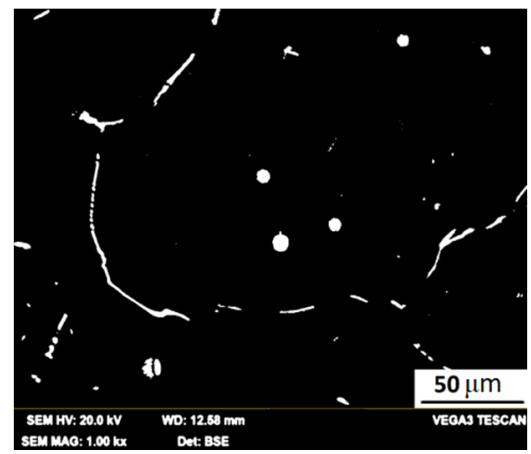

(c)
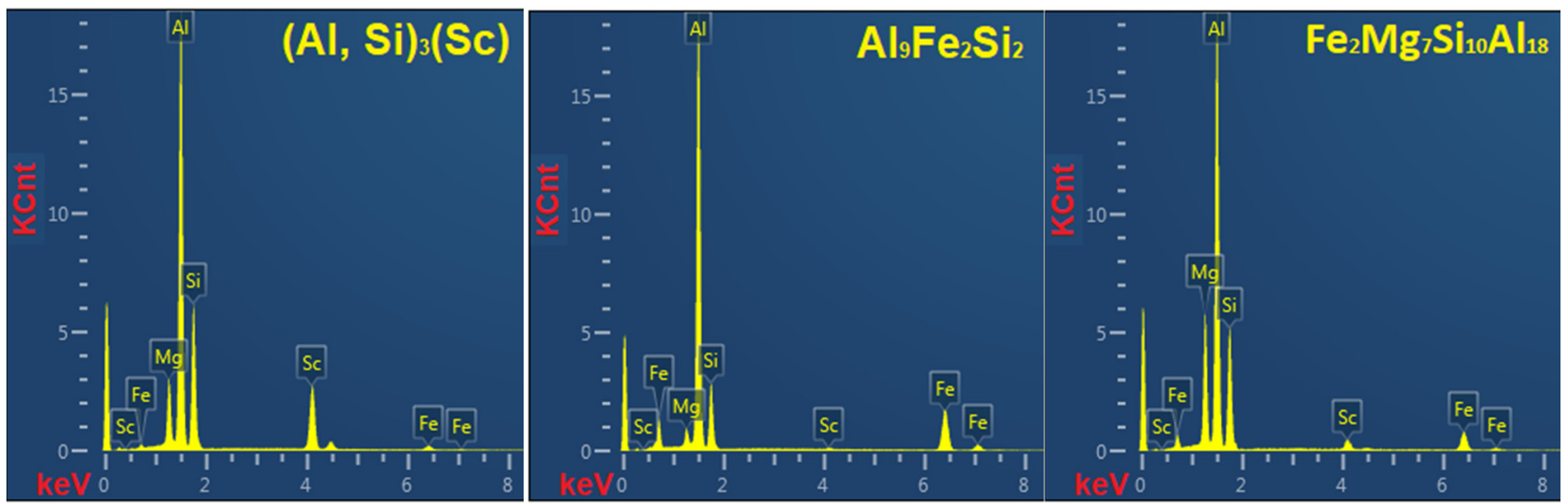

(d)

Figure 8. $\mathrm{Al}_{0.5} \mathrm{Mg}_{1.3} \mathrm{Si}_{0.3} \mathrm{Sc}$ main types of intermetallic compounds (a); small dispersoids (b); large particles (c); result of the EDS investigation of chemical composition of the intermetallic compounds (d).

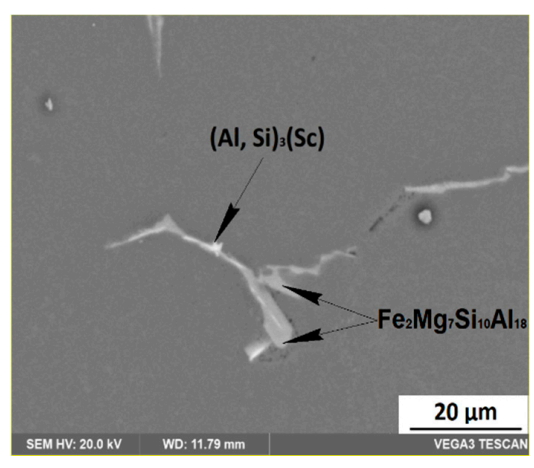

(a)

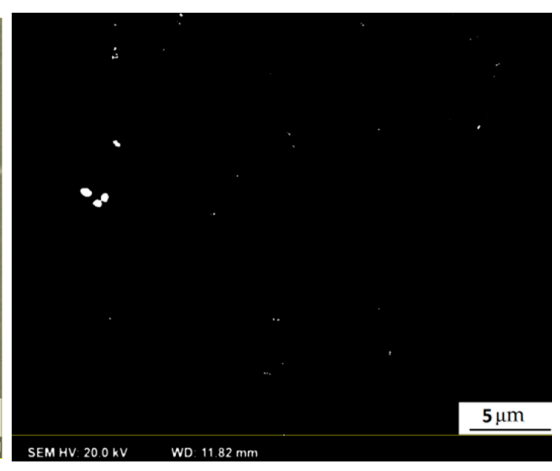

(b)

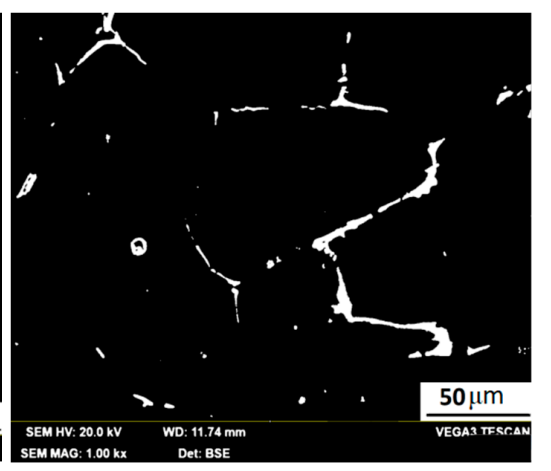

(c)

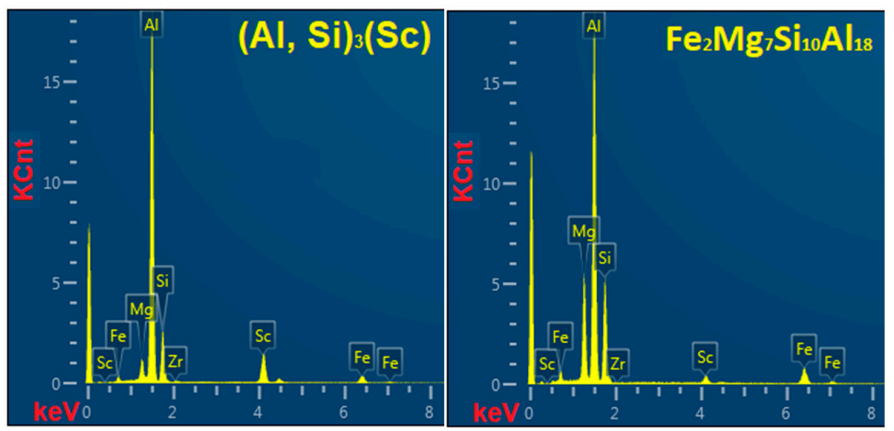

(d)

Figure 9. $\mathrm{Al}_{0.5} \mathrm{Mg}_{1.3} \mathrm{Si}_{0.3} \mathrm{Sc}_{0.15} \mathrm{Zr}$ main types of intermetallic compounds (a); small dispersoids (b); large particles (c); result the EDS investigation of chemical composition of the intermetallic compounds (d). 
Table 2. Size and amount of dispersoids in the investigated alloys.

\begin{tabular}{cccc}
\hline Alloy & Area Share, $\%$ & $\begin{array}{c}\text { Average Amount per } \\
\mathbf{5 0 0} \mathbf{~ M i c r o n s ~}^{2}\end{array}$ & Average Size, $\boldsymbol{\mu m}^{\text {Am }}$ \\
\hline $\mathrm{Al}_{0.3} \mathrm{Mg}_{1} \mathrm{Si}_{0.3} \mathrm{Sc}$ & 0.14 & 21 & 0.05 \\
\hline $\mathrm{Al}_{0.5} \mathrm{Mg}_{1.3} \mathrm{Si}_{0.3} \mathrm{Sc}$ & 0.87 & 3 & 0.59 \\
\hline $\mathrm{Al}_{0.3} \mathrm{Mg}_{1 \mathrm{Si}_{0.3} \mathrm{Sc}_{0.15} \mathrm{Zr}}$ & 0.2 & 16 & 0.08 \\
\hline $\mathrm{Al}_{0.5} \mathrm{Mg}_{1.3} \mathrm{Si}_{0.3} \mathrm{Sc}_{0.15} \mathrm{Zr}$ & 0.11 & 21 & 0.03 \\
\hline
\end{tabular}

Table 3. Size and amount of intermetallic compounds in the investigated alloys.

\begin{tabular}{cccc}
\hline Alloy & Area Share, \% & $\begin{array}{c}\text { Average Amount per } \\
\text { 500 Microns } \mathbf{2}^{2}\end{array}$ & Average Size, $\boldsymbol{\mu m}$ \\
\hline $\mathrm{Al}_{0.3} \mathrm{Mg}_{1} \mathrm{Si}_{0.3} \mathrm{Sc}$ & 2.15 & 90 & 12.4 \\
$\mathrm{Al}_{0.5} \mathrm{Mg}_{1.3} \mathrm{Si}_{0.3} \mathrm{Sc}$ & 1.5 & 71 & 10.6 \\
$\mathrm{Al}_{0.3} \mathrm{Mg}_{1} \mathrm{Si}_{0.3} \mathrm{Sc}_{0.15} \mathrm{Zr}$ & 1.8 & 78 & 11.6 \\
$\mathrm{Al}_{0.5} \mathrm{Mg}_{1.3} \mathrm{Si}_{0.3} \mathrm{Sc}_{0.15} \mathrm{Zr}$ & 1.7 & 69 & 12.8 \\
\hline
\end{tabular}

Table 4. Chemical composition of intermetallic particles in the studied alloys.

\begin{tabular}{|c|c|c|c|c|c|c|c|}
\hline \multirow{2}{*}{ Alloy } & \multirow{2}{*}{ Phase } & \multicolumn{6}{|c|}{ At. $\%$} \\
\hline & & Al & $\mathrm{Fe}$ & Si & $\mathrm{Mg}$ & Sc & $\mathrm{Zr}$ \\
\hline \multirow{3}{*}{$\mathrm{Al}_{0.3} \mathrm{Mg}_{1} \mathrm{Si}_{0.3} \mathrm{Sc}$} & $\mathrm{Fe}_{2} \mathrm{Mg}_{7} \mathrm{Si}_{10} \mathrm{Al}_{18}$ & 58.54 & 4.1 & 13.91 & 22.44 & & \\
\hline & $\mathrm{Al}_{9} \mathrm{Fe}_{2} \mathrm{Si}_{2}$ & 76.69 & 9.7 & 10.01 & & & \\
\hline & Solid solution & 98.23 & & 0.48 & 0.27 & 0.11 & \\
\hline \multirow{4}{*}{$\mathrm{Al}_{0.5} \mathrm{Mg}_{1.3} \mathrm{Si}_{0.3} \mathrm{Sc}$} & $\mathrm{Al}_{9} \mathrm{Fe}_{2} \mathrm{Si}_{2}$ & 66.17 & 14.46 & 16.02 & & & \\
\hline & $\mathrm{Fe}_{2} \mathrm{Mg}_{7} \mathrm{Si}_{10} \mathrm{Al}_{18}$ & 53.99 & 5.35 & 15.43 & 23.6 & & \\
\hline & $(\mathrm{Al}, \mathrm{Si})_{3}(\mathrm{Sc})$ & 51.65 & 27.02 & 11.93 & & & \\
\hline & Solid solution & 98.7 & & 0.79 & 0.4 & 0.12 & \\
\hline \multirow{5}{*}{$\mathrm{Al}_{0.3} \mathrm{Mg}_{1} \mathrm{Si}_{0.3} \mathrm{Sc}_{0.15} \mathrm{Zr}$} & $\mathrm{Fe}_{2} \mathrm{Mg}_{7} \mathrm{Si}_{10} \mathrm{Al}_{18}$ & 66.04 & 3.14 & 9.94 & 19.95 & & \\
\hline & $\mathrm{Al}_{9} \mathrm{Fe}_{2} \mathrm{Si}_{2}$ & 60.11 & 7.08 & 22.66 & & & \\
\hline & $(\mathrm{Al}, \mathrm{Si})_{3}(\mathrm{Sc})$ & 61.83 & & 24 & & 7.06 & \\
\hline & $\mathrm{Al}_{3}\left(\mathrm{Sc}_{0.6} \mathrm{Zr}_{0.4}\right)$ & 82.88 & & & & 11.44 & 4.61 \\
\hline & Solid solution & 98.72 & & 0.82 & 0.28 & 0.14 & 0.04 \\
\hline \multirow{3}{*}{$\mathrm{Al}_{0.5} \mathrm{Mg}_{1.3} \mathrm{Si}_{0.3} \mathrm{Sc}_{0.15} \mathrm{Zr}$} & $\mathrm{Fe}_{2} \mathrm{Mg}_{7} \mathrm{Si}_{10} \mathrm{Al}_{18}$ & 54.08 & 5.3 & 15 & 24.11 & & \\
\hline & $(\mathrm{Al}, \mathrm{Si})_{3}(\mathrm{Sc})$ & 66.9 & 16.94 & & & 8.33 & \\
\hline & Solid solution & 99.32 & & 0.21 & 0.32 & 0.1 & 0.05 \\
\hline
\end{tabular}

It must be mentioned that most of the phases listed in Tables 2-4 are non-equilibrium, as result they cannot be predicted by the diagram. The reason for this is the non-equilibrium conditions of solidification and the inevitable presence of iron even in the high frequency batch. However, the diagram on Figure 6 can be very useful for predicting phase transformations after homogenization annealing (for example, combined with quenching) when the composition is close to equilibrium.

\subsection{Investigation of the Despersoid by Transmission Electron Microscopy (TEM) Method}

A sufficiently large number of $\mathrm{Al}_{3} \mathrm{Sc}$ particles is observed in the alloy $\mathrm{Al}_{0.3} \mathrm{Mg}_{1} \mathrm{Si}_{0.3} \mathrm{Sc}$. The size of these particles is $20 \mathrm{~nm}$ on average (Figure 10a,b). Particles of a given size are at the coherence loss thresholds. Therefore, some of them are completely coherent (Figure 10d), while others only partially (Figure 10d). The presented data are in good agreement with the data of scanning microscopy, according to which most of the scandium is not in a supersaturated solid solution, and at the same time, it is not observed in large particles of eutectic origin, such as $\mathrm{Al}_{0.3} \mathrm{Mg}_{1} \mathrm{Si}_{0.3} \mathrm{Sc}_{0.15} \mathrm{Zr}$. In addition, it is the particles of this type that serve as the main reason for the growth of microhardness (see Figure $4 \mathrm{a}$ ). It should 
also be noted that these particles contain unwanted silicon. However, considering that these particles are fully or partially coherent and considering the increase in microhardness, it is possible with a high degree of probability that they are metastable ( $\mathrm{AlSi})_{3} \mathrm{Sc}$, rather than equilibrium harmful $\mathrm{AlSc}_{2} \mathrm{Si}_{2}$. The appearance of such particles during solidification in the 6XXX series alloys with small additions of scandium and zirconium as a result of discontinuous precipitation has already been described in many investigations [40,41]. However, it has been described mainly in alloys that do not have such a high excess of silicon. The presence of metastable coherent and semi-coherent particles which precipitate during the cooling process after casting of the $\mathrm{Al}_{0.3} \mathrm{Mg}_{1} \mathrm{Si}_{0.3} \mathrm{Sc}$ alloy indicates that they can also be obtained as a result of multistage heat treatment. Thus, the cooling rate achieved in a steel chill mold without zirconium is insufficient so that (AlSi) ${ }_{3} \mathrm{Sc}$-type particles are not precipitated during cooling. It should be noted that in spite the short cooling time of the ingot, a large number of $(\mathrm{AlSi})_{3} \mathrm{ScZr}$ dispersoids precipitate in this and other alloys investigated by TEM. This can be explained by the fact that silicon accelerates the kinetics of the precipitation of $(\mathrm{AlSi})_{3} \mathrm{ScZr}[42]$.

A different picture of the distribution and chemical composition of fine particles is observed in the $\mathrm{Al}_{0.5} \mathrm{Mg}_{1.3} \mathrm{Si}_{0.3} \mathrm{Sc}$ alloy. It also contains the (AlSi) $)_{3} \mathrm{Sc}$-type particles but their number is somewhat less than in the $\mathrm{Al}_{0.3} \mathrm{Mg}_{1} \mathrm{Si}_{0.3} \mathrm{Sc}$ alloy (Figure 11a). However, in general, they have the same size and the same chemical composition. In addition, needle-shaped particles similar to $\beta^{\prime \prime}\left(\mathrm{Mg}_{5} \mathrm{Si}_{6}\right)$ appear (Figure $\left.11 \mathrm{~b}, \mathrm{c}\right)$.

It should be noted that in spite of the rather short cooling time of the ingot, a large number of $\mathrm{Al}_{3} \mathrm{ScZr}$ particles precipitate in this (and other alloys investigated by TEM). This can be explained by the fact that silicon accelerates the kinetics of the precipitation of these particles.

Note that emerging of $\beta^{\prime \prime}$ actually became possible due to the fact that additional magnesium appeared for the reaction with silicon. Thus, an increase in the $\mathrm{Mg} / \mathrm{Si}$ ratio will contribute to obtaining an additional synergistic effect between the (AlSi) $)_{3} \mathrm{Sc}$ and $\beta^{\prime \prime}$ $\left(\mathrm{Mg}_{5} \mathrm{Si}_{6}\right)$ particles. In general, the cooling rates after casting in a steel chill mold are also insufficient in this alloy to contain the main elements in a solid solution, and they form hardening phases ( $\mathrm{AlSi})_{3} \mathrm{Sc}$ and $\beta^{\prime \prime}\left(\mathrm{Mg}_{5} \mathrm{Si}_{6}\right)$.

The $\mathrm{Al}_{0.3} \mathrm{Mg}_{1} \mathrm{Si}_{0.3} \mathrm{Sc}_{0.15} \mathrm{Zr}$ alloy contains a fairly large number of fine coherent or semicoherent $(\mathrm{AlSi})_{3} \mathrm{ScZr}$ particles with the $\mathrm{L}_{2}$-structure (Figure $12 \mathrm{~b}-\mathrm{d}$ ). At the same time, there is a second type of elongated particles (Figure 12a,c), which can be confused with $\beta^{\prime \prime}$ $\left(\mathrm{Mg}_{5} \mathrm{Si}_{6}\right)$, given the rather high content of magnesium as well as silicon in the surrounding solid solution. However, these particles are much longer than $\beta^{\prime \prime}\left(\mathrm{Mg}_{5} \mathrm{Si}_{6}\right)$ (from 0.5 to $1 \mu \mathrm{m}$ ). Therefore, a chemical analysis (Figure 12e) shows that they are also discontinuous precipitation of $(\mathrm{AlSi})_{3} \mathrm{ScZr}$ particles. This fact is also confirmed by the comparison with the literature data [43], in which discontinuous $\mathrm{Al}_{3} \mathrm{Sc}$ precipitates are practically identical in shape, size and location of relatively high-angle boundaries compared to the dispersoids observed in this work. It should be noted that, as in Ref. [44], high-angle boundaries serve as a source of discontinuous precipitation of the ( $\mathrm{AlSi})_{3} \mathrm{ScZ}$ r-type dispersoids. When these particles are precipitated, energy is released and the high-angle boundaries begin to move, leaving behind a large number of the ( $\mathrm{AlSi})_{3} \mathrm{ScZr}$-type dispersoids. It is noteworthy that dendritic grains, in which intermittent precipitates are found, do not contain $\mathrm{L1}_{2}$-nanoparticles (Figure 12c) and vice versa. A possible explanation for this is that in discontinuous precipitation, as in recrystallization [45], there are orientations more favorable for the motion of high-angle boundaries. In grains with an intermittent release of $(\mathrm{AlSi})_{3} \mathrm{ScZr}$, scandium and zirconium become insufficient for the appearance of more coherent particles which have $\mathrm{L}_{2}$-structure. It should be noted that, in the case of the $\mathrm{Al}_{0.3} \mathrm{Mg}_{1} \mathrm{Si}_{0.3} \mathrm{Sc}$ alloy, $\beta^{\prime \prime}\left(\mathrm{Mg}_{5} \mathrm{Si}_{6}\right)$ particles can be observed together with ( $\left.\mathrm{AlSi}\right)_{3} \mathrm{Sc}$ particles, in contrast to the $\mathrm{L}_{2}$ and needle shape (AlSi) ${ }_{3} \mathrm{ScZr}$ dispersoids. It can also be noted that for the discontinuous and simultaneous precipitation both needle-shaped and L1-structured dispersoids the concentration of scandium in the $\mathrm{Al}_{0.3} \mathrm{Mg}_{1} \mathrm{Si}_{0.3} \mathrm{Sc}$ and $\mathrm{Al}_{0.5} \mathrm{Mg}_{1.3} \mathrm{Si}_{0.3} \mathrm{Sc}$ alloys is insufficient. 


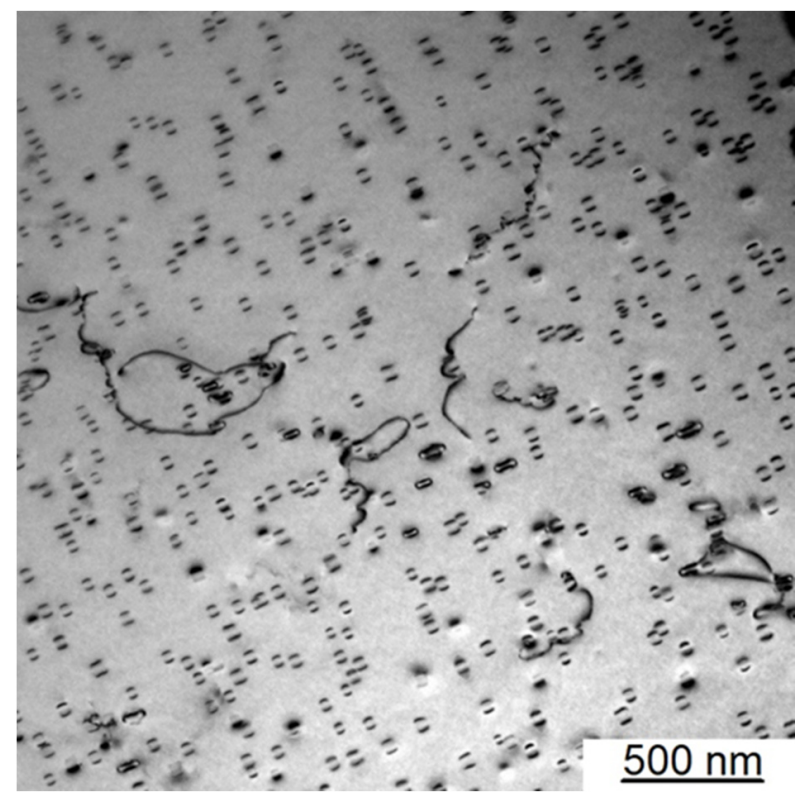

(a)
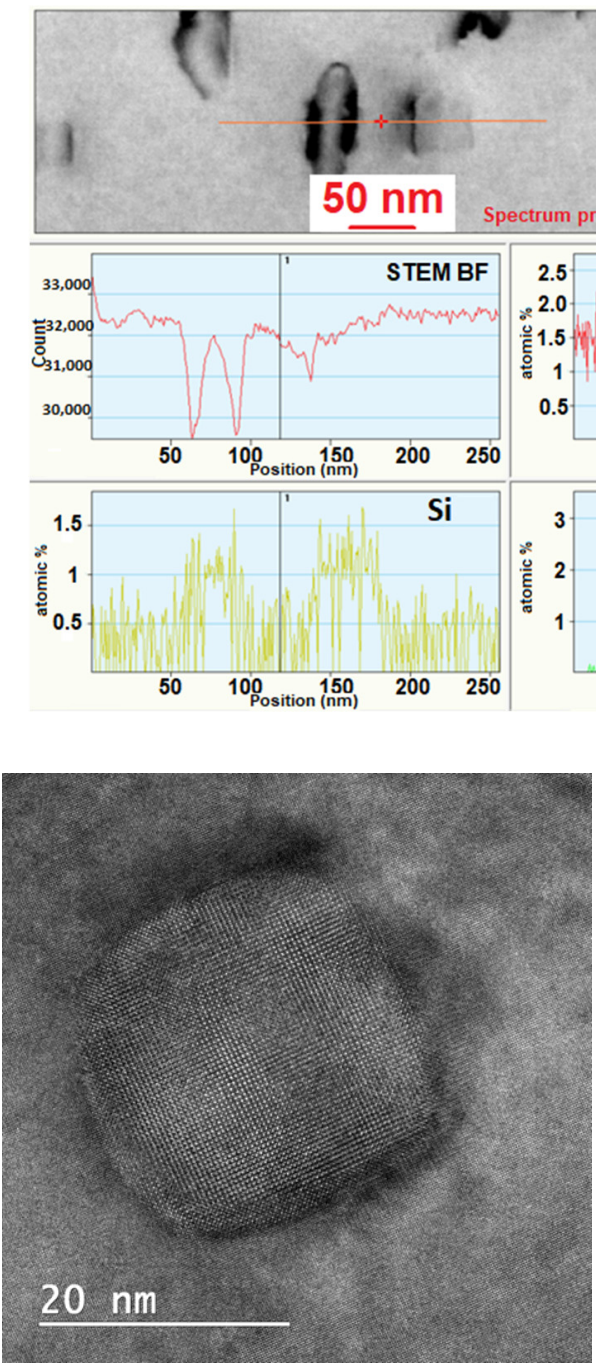

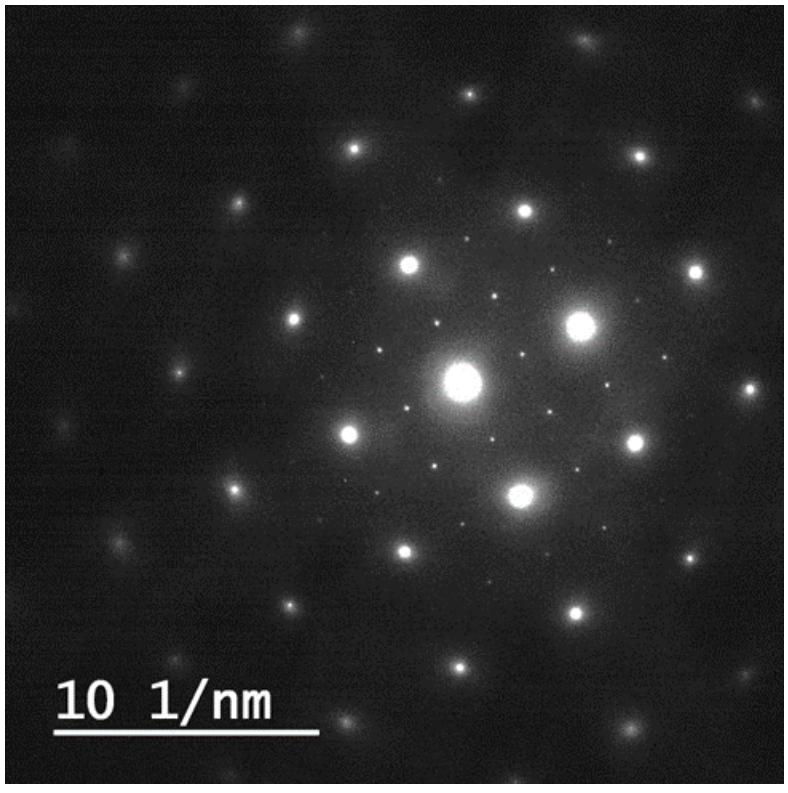

(b)
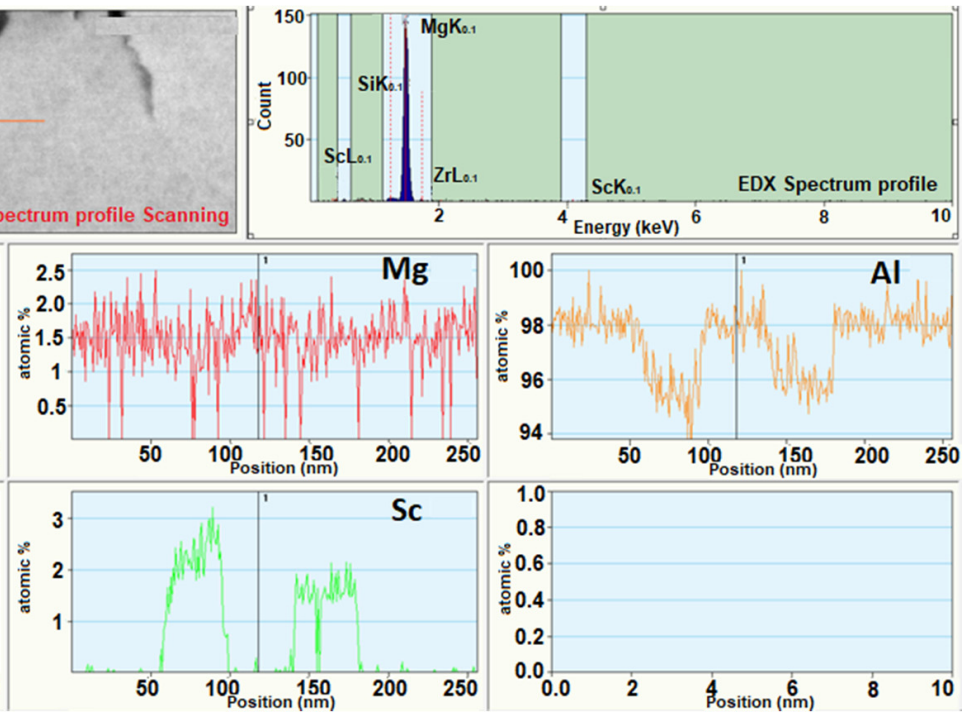

(c)
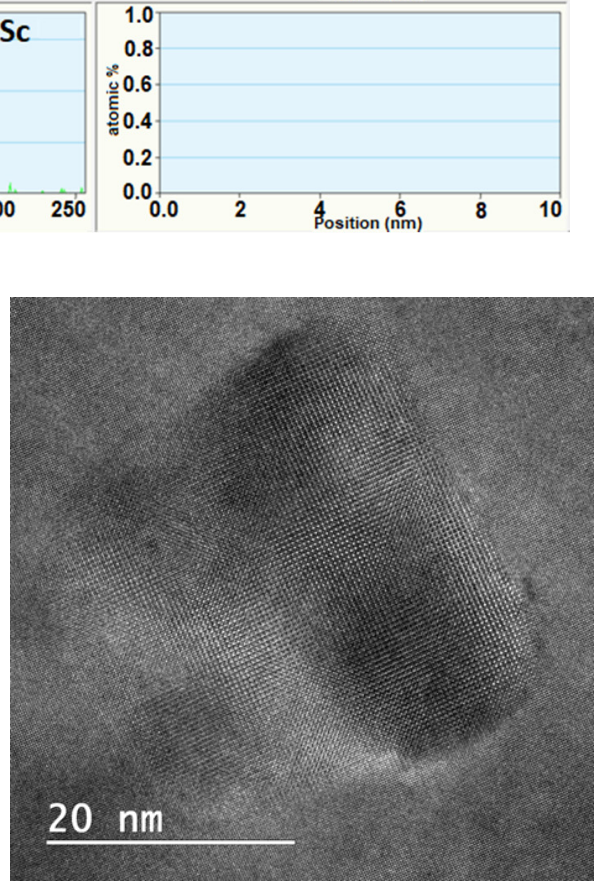

(d)

Figure 10. (a) (AlSi) ${ }_{3} \mathrm{Sc}$ coherent and semi coherent particles, (b) EDS profile line scan; (c,d) direct resolution of the crystal lattice with $(\mathrm{AlSi})_{3} \mathrm{Sc}$ particles of various sizes. 


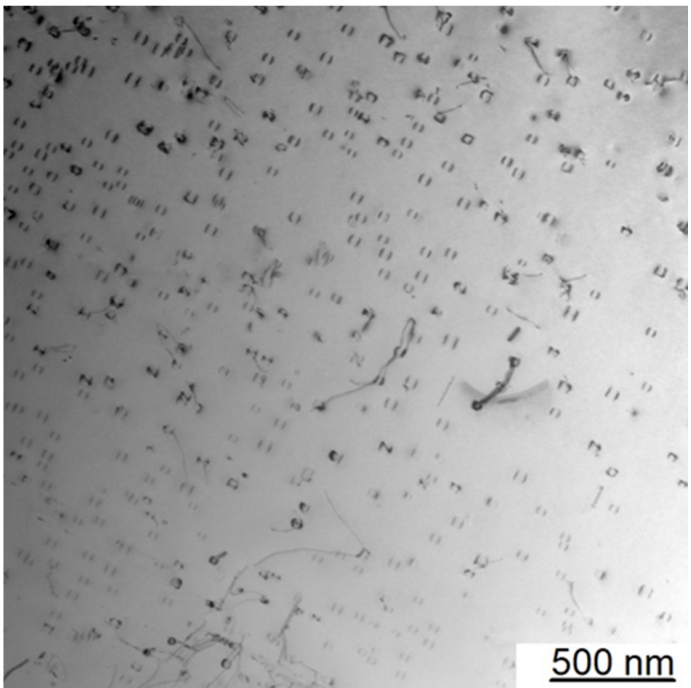

(a)

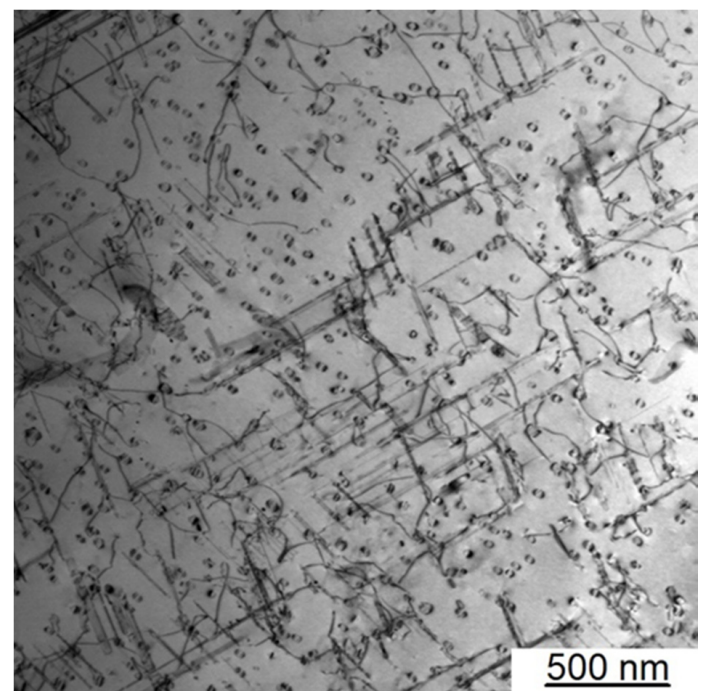

(b)
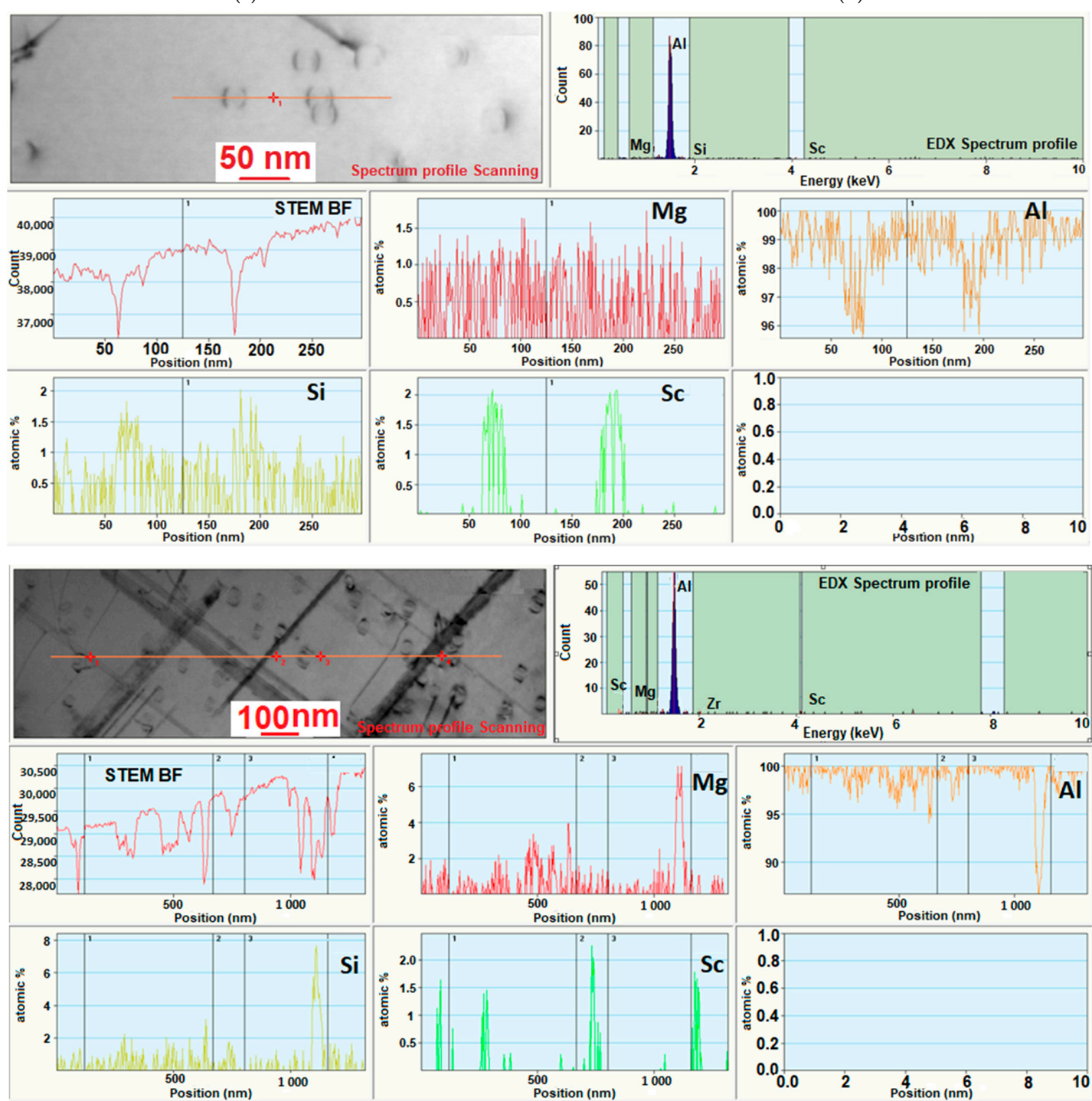

Si
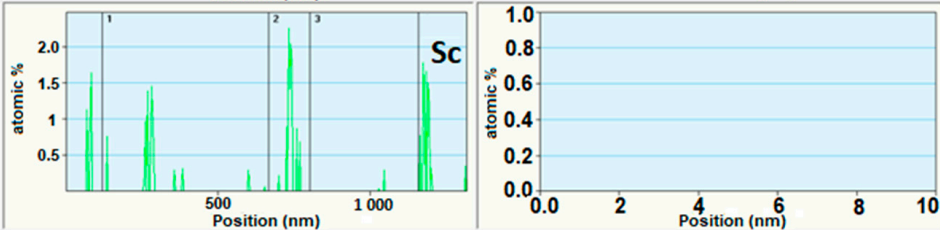

(c)

Figure 11. (a) $\mathrm{Al}_{3} \mathrm{Sc}$ coherent and semi coherent particles particles; (b) $\mathrm{Al}_{3} \mathrm{Sc}$ coherent and semi coherent particles $+\mathrm{Mg}_{2} \mathrm{Si}$ (rod-like) particles (c) EDS profile line scan. 


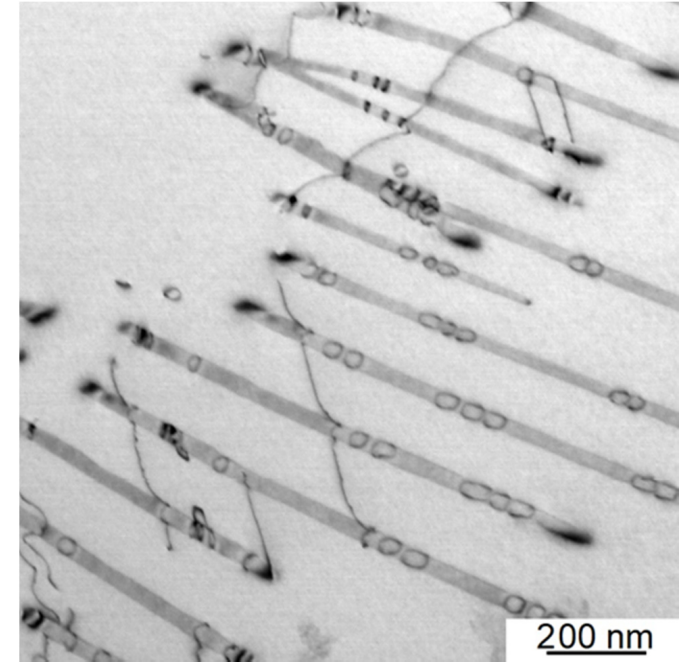

(a)

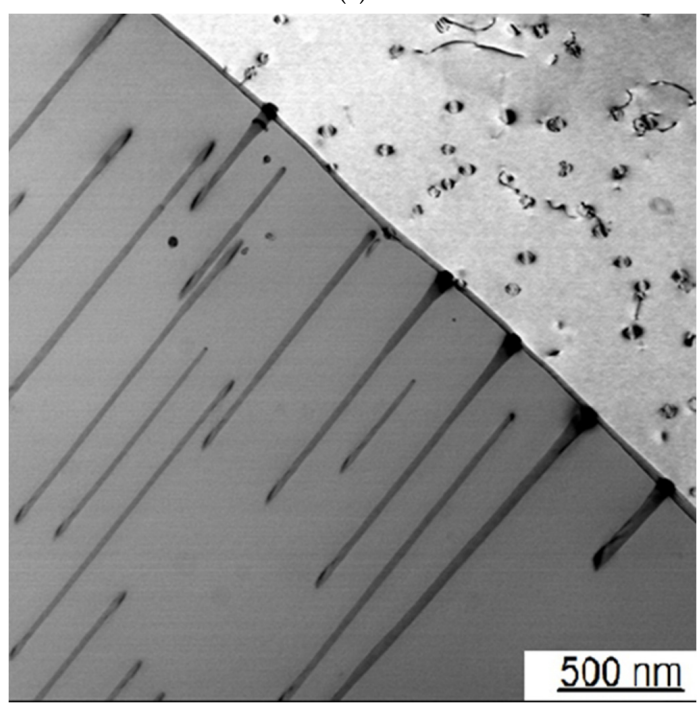

(c)

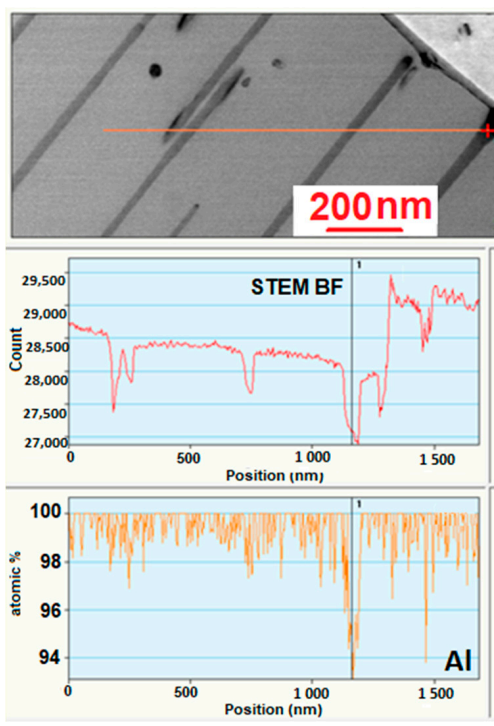

$500 \mathrm{~nm}$
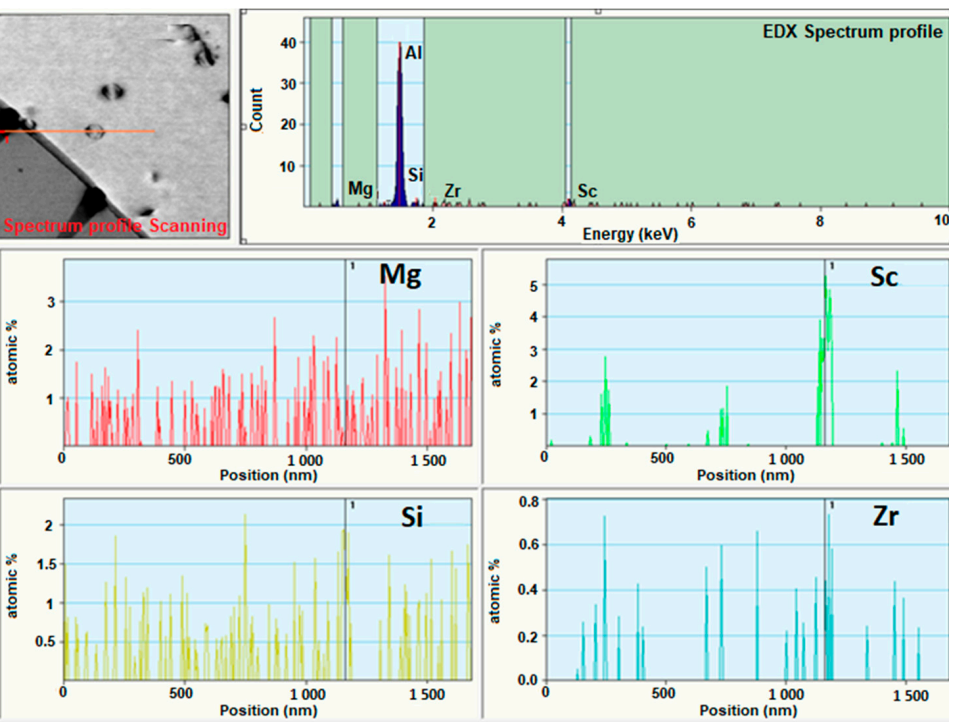

(e)

Figure 12. (a,c,d) Discontinuous precipitation of $(\mathrm{AlSi})_{3} \mathrm{ScZ}$ r needle-shaped particles; (b) (AlSi) $)_{3} \mathrm{ScZr}$ particles with the $\mathrm{L1}_{2}$-structure, (c) discontinuous precipitation of $(\mathrm{AlSi})_{3} \mathrm{ScZr}$ needle-shaped particles near high-angle boundaries. (e) EDS profile line scan. 
Mainly coherent or semi-coherent $(\mathrm{AlSi})_{3} \mathrm{ScZr}$-particles, which have the $\mathrm{L1}_{2}$-structure (Figure 13a,b), are formed during discontinuous precipitation and are observed in the $\mathrm{Al}_{0.5} \mathrm{Mg}_{1.3} \mathrm{Si}_{0.3} \mathrm{Sc}_{0.15} \mathrm{Zr}$ alloy. The lack of needle-shape precipitates is most likely due to the limitations of TEM associated with the small area observed. The average grain size in this alloy is $260 \mu \mathrm{m}$, while the survey area is $4 \mu \mathrm{m}^{2}$, at best. For the alloy $\mathrm{Al}_{0.3} \mathrm{Mg}_{1.3} \mathrm{Si}_{0.3} \mathrm{Sc}_{0.15} \mathrm{Zr}$, where the grain is finer, it is easier to find grain boundaries around which intermittent precipitates are concentrated. In the case of $\mathrm{Al}_{0.3} \mathrm{Mg}_{1} \mathrm{Si}_{0.3} \mathrm{Sc}_{0.15} \mathrm{Zr}$, the $\beta^{\prime \prime}\left(\mathrm{Mg}_{5} \mathrm{Si}_{6}\right)$-phase is not detected in the alloy. Its absence can be explained by the fact that the bulk of magnesium and silicon form primary $\mathrm{Mg}_{2} \mathrm{Si}$-particles at this concentration of zirconium and scandium (see Figure 6).

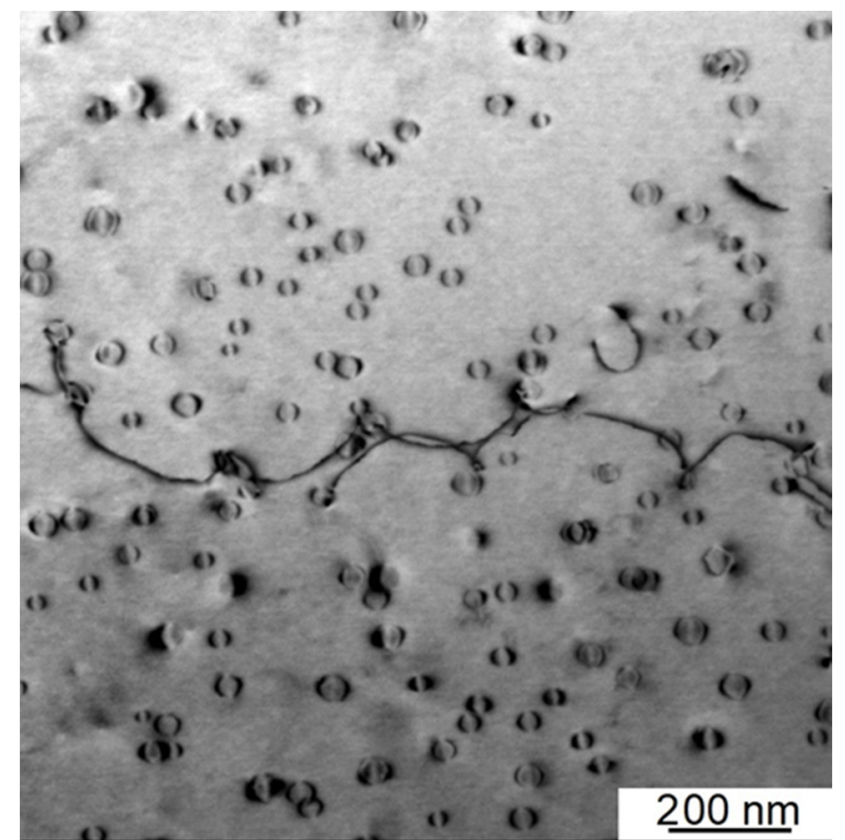

(a)

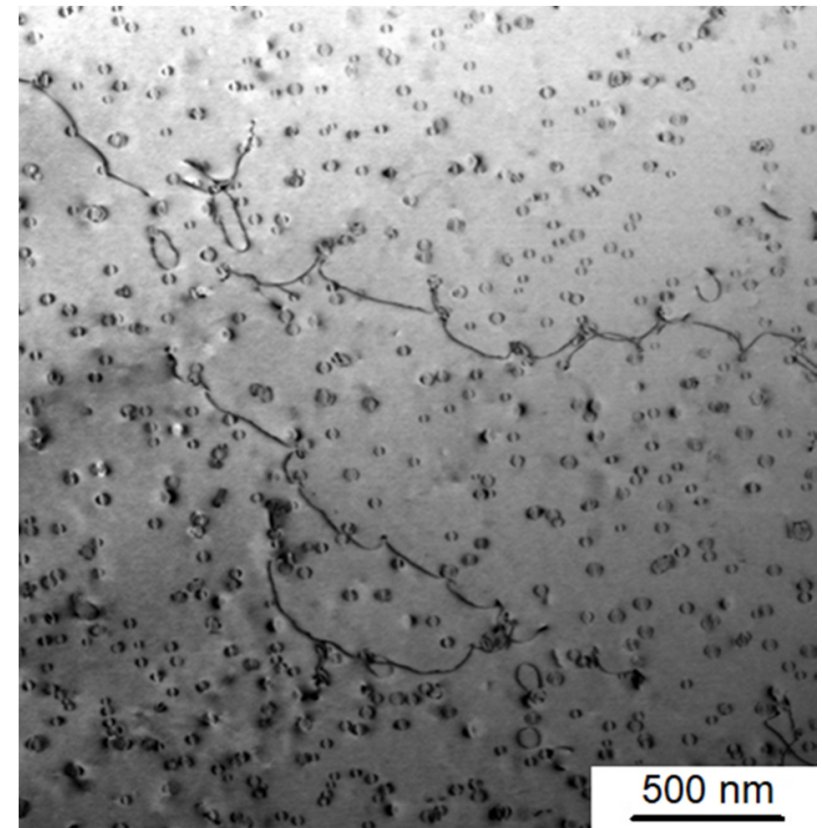

(b)
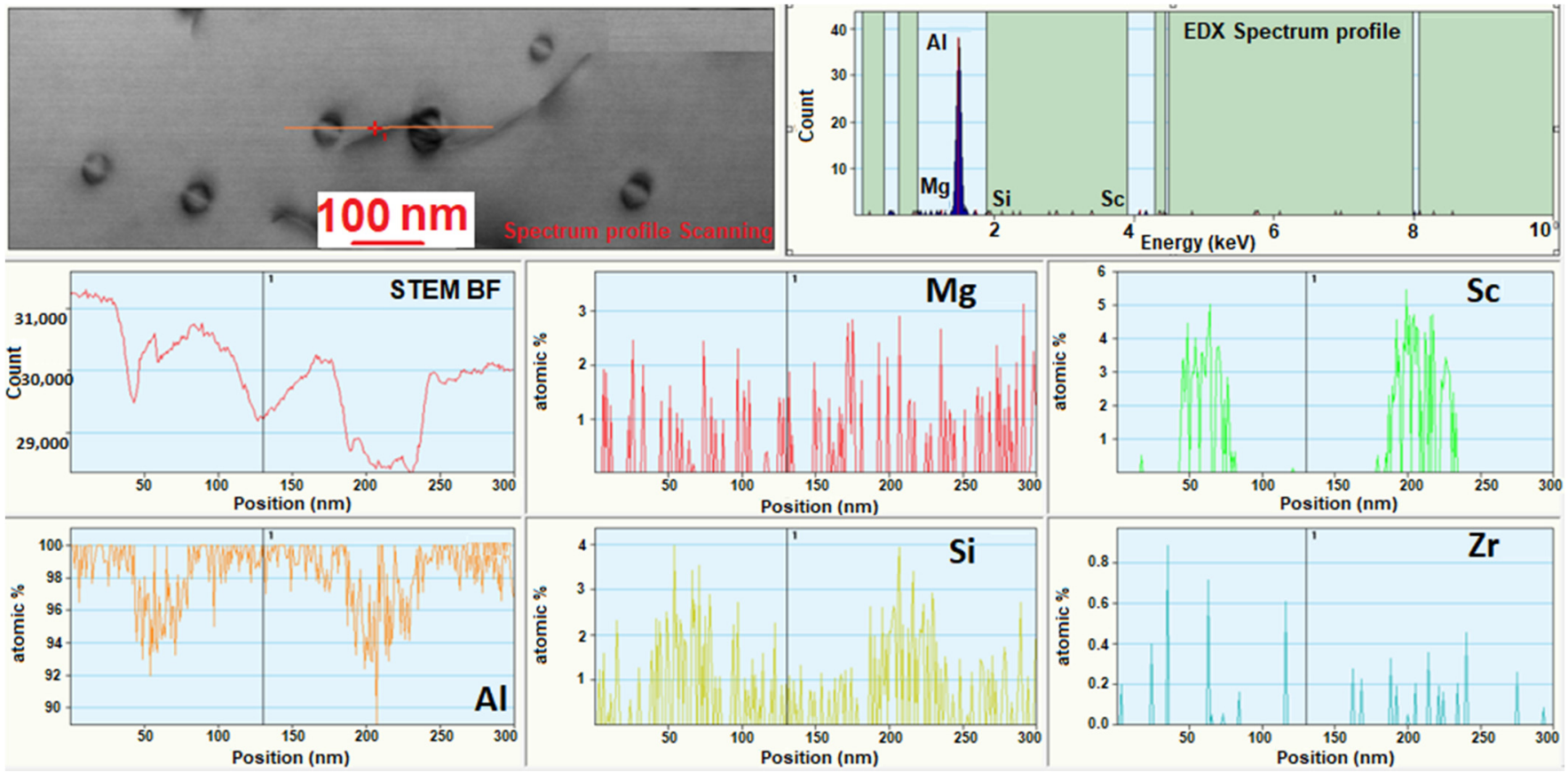

(c)

Figure 13. (a,b) (AlSi) $)_{3} \mathrm{ScZr}$ particles with the $\mathrm{L}_{2}$ structure, (c) EDS profile line scan. 


\section{Conclusions}

Variations of $\mathrm{Mg}$ within $0.3 \div 0.5 \%$; Si within $1 \div 1.3 \%$; Sc within $0.0 \div 0.3 \%$; $\mathrm{Zr}$ in the range of $0.0 \div 0.15 \%$ have a complex effect on the microstructure formed during casting of these alloys. The most significant effect on the size of the grain structure is exerted by micro-additives of $\mathrm{Sc}$ and $\mathrm{Zr}$. In $\mathrm{Al}_{0.3} \mathrm{Mg}_{1} \mathrm{Si}$ alloys, the complex additive ${ }_{0.3} \mathrm{Sc}_{0.15} \mathrm{Zr}$ is able to refine the grain size by seven times. The refinement of the grain structure is influenced by two main factors: supercooling at the boundaries of the nucleus and the liquid phase, and the formation of $\mathrm{Al}_{3} \mathrm{Sc}$ particles in the liquid. The latter takes place at a concentration of $0.15 \%$ zirconium and $0.24 \%$ scandium in $\mathrm{Al}_{0.3} \mathrm{Mg}_{1}$ Si alloys and $0.15 \%$ zirconium and $0.28 \%$ scandium in $\mathrm{Al}_{0.5} \mathrm{Mg}_{1.3} \mathrm{Si}$ alloys. The refinement of the grain structure by supercooling is more efficient in the $\mathrm{Al}_{0.5} \mathrm{Mg}_{1.3} \mathrm{Si}$ alloys, and with the primary $\mathrm{Al}_{3} \mathrm{Sc}$ phase in the alloys of the $\mathrm{Al}_{0.3} \mathrm{Mg}_{1} \mathrm{Si}$ type, where the scandium concentration required for the formation of this phase is reached earlier.

These alloys have a complex phase composition. After casting, it can be represented by both equilibrium and non-equilibrium phases; in addition, iron impurities have a significant effect. With regards to maximum binding of scandium to other elements, the preferable alloys are $\mathrm{Al}_{0.5} \mathrm{Mg}_{1.3} \mathrm{Si}$. However, the $\mathrm{Al}_{0.3} \mathrm{Mg}_{1} \mathrm{Si}$ alloy is better for the effective dissolution of the $\mathrm{Mg}_{2} \mathrm{Si}$ phase, which occurs already at $450{ }^{\circ} \mathrm{C}$. In general, compositions with combined alloying by small additions of $\mathrm{Sc}$ and $\mathrm{Zr}$ and mono additions of $\mathrm{Zr}$ seem to be most promising. Alloying Sc compositions with such an excess of silicon is practically unpromising.

The cooling time after solidification of the ingot is sufficient for the precipitation of fine particles. These particles are practically not tracked using scanning electron microscope SEM even at high magnification. However, they are very clearly identified using TEM, as well as by an increase in microhardness. The main type of particles is ( $\mathrm{AlSi})_{3} \mathrm{Sc}$ or $(\mathrm{AlSi})_{3} \mathrm{ScZr}$, depending on the presence or absence of zirconium. These particles appear during discontinuous precipitates in form of the $\mathrm{L}_{2}$-structure with dimensions of $15-20 \mathrm{~nm}$ and are semi- and completely coherent or in needle shape form (observed only in alloys with zirconium). The formation of coherent and semi-coherent particles in these alloys opens the possibility for their further production during heat treatment. $\beta^{\prime \prime}\left(\mathrm{Mg}_{5} \mathrm{Si}_{6}\right)$ particles are formed only in the alloy $\mathrm{Al}_{0.5} \mathrm{Mg}_{1.3} \mathrm{Si}_{0.3} \mathrm{Sc}$, where there is enough magnesium for their precipitation. The addition of zirconium changes the phase composition and promotes the precipitation of large $\mathrm{Mg}_{2} \mathrm{Si}$-type particles.

Author Contributions: Conceptualization, E.A. and S.K.; methodology, E.A., S.K. and J.H.; software, E.A. and S.K.; validation, E.A., S.K. and J.H.; formal analysis, E.A. and A.D.; investigation, E.A., M.L., V.B. and D.Z.; resources, E.A., J.H. and S.K.; data curation, E.A., J.H., S.K. and A.D.; writing-original draft preparation, E.A., J.H. and S.K.; writing-review and editing, E.A., J.H. and S.K.; visualization, E.A. and J.H.; supervision, S.K.; project administration, E.A. and S.K.; funding acquisition, S.K. All authors have read and agreed to the published version of the manuscript.

Funding: This study is funded by a grant of the Russian Science Foundation, project 21-19-00548, https:/ /rscf.ru/project/21-19-00548/.

Institutional Review Board Statement: Not applicable.

Informed Consent Statement: Not applicable.

Data Availability Statement: The data presented in this study are available on request from the corresponding author.

Conflicts of Interest: The authors declare no conflict of interest.

\section{References}

1. Fedorov, S.; Nanocomposites, V.B. Development of Mechanical Properties of Aluminum-Silicon Alloys. Smart Nanocompos. 2015, 6, 199-202.

2. Bazhin, V.Y.; Gutema, E.M.; Savchenkov, S.A. Production Technology Features for Aluminum Matrix Alloys with a Silicon Carbide Framework. Metallurgist 2017, 60, 1267-1272. [CrossRef] 
3. Deev, V.B.; Degtyar, V.A.; Kutsenko, A.I.; Selyanin, I.F.; Voitkov, A.P. Resource-Saving Technology for the Production of Cast Aluminum Alloys. Steel Transl. 2007, 37, 991-994. [CrossRef]

4. Akopyan, T.K.; Letyagin, N.V.; Belov, N.A.; Koshmin, A.N.; Gizatulin, D.S. Analysis of the Microstructure and Mechanical Properties of a New Wrought Alloy Based on the ((Al) + Al4(Ca,La)). Eutectic. Phys. Met. Metallogr. 2020, 121, 914-919. [CrossRef]

5. Sizyakov, V.M.; Bazhin, V.Y.; Vlasov, A.A. Status and Prospects for Growth of the Aluminum Industry. Metallurgist 2010, 54, 409-414. [CrossRef]

6. Belov, N.; Akopyan, T.; Korotkova, N.; Murashkin, M.; Timofeev, V.; Fortuna, A. Structure and Properties of Ca and Zr Containing Heat Resistant Wire Aluminum Alloy Manufactured by Electromagnetic Casting. Metals 2021, 11, 236. [CrossRef]

7. Hirsch, J. Aluminium in Innovative Light-Weight Car Design. Mater. Trans. 2011, 52, 818-824. [CrossRef]

8. Lamberti, M.; Escher, F. Aluminium Foil as a Food Packaging Material in Comparison with Other Materials. Food Rev. Int. 2007, 23, 407-433. [CrossRef]

9. Miller, W.S.; Zhuang, L.; Bottema, J.; Wittebrood, A.J.; De Smet, P.; Haszler, A.; Vieregge, A. Recent Development in Aluminium Alloys for the Automotive Industry. Mater. Sci. Eng. 2000, 280, 37-49. [CrossRef]

10. Rambabu, P.; Eswara Prasad, N.; Kutumbarao, V.V.; Wanhill, R.J.H. Aluminium Alloys for Aerospace Applications. In Aerospace Materials and Material Technologies; Prasad, N., Wanhill, R., Eds.; Indian Institute of Metals Series; Springer: Singapore, 2017; pp. 29-52. [CrossRef]

11. Pogatscher, S.; Antrekowitsch, H.; Werinos, M.; Moszner, F.; Gerstl, S.S.A.; Francis, M.F.; Curtin, W.A.; Löffler, J.F.; Uggowitze, P.J. Diffusion on demand to control precipitation aging: Application to Al-Mg-Si alloys. Phys. Rev. Lett. 2014, 22, 225701. [CrossRef]

12. Liu, C.; Zhang, X.; Tang, J.; Liu, X.; Liang, C. Effect of copper on precipitation and baking hardening behavior of Al-Mg-Si alloys. Trans. Nonferrous Met. Soc. China 2014, 7, 2289-2294. [CrossRef]

13. Kim, J.H.; Kobayashi, E.; Sato, T. Effects of $\mathrm{Cu}$ addition on behavior of nanoclusters during multi-step aging in Al-Mg-Si alloy. Mater. Trans. 2011, 5, 906-913. [CrossRef]

14. Hong, L.I.U.; Gang, Z.; Liu, C.M.; Liang, Z. Effects of different tempers on precipitation hardening of 6000 series aluminium alloys. Trans. Nonferrous Met. Soc. China 2007, 1, 122-127.

15. Liang, Z. Clustering and Precipitation in Al-Mg-Si Alloys. Ph.D. Thesis, Technische Universität Berlin, Berlin, Germany, 28 November 2012.

16. Werinos, M.; Antrekowitsch, H.; Ebner, T.; Prillhofer, R.; Curtin, W.A.; Uggowitzer, P.J.; Pogatscher, S. Design strategy for controlled natural aging in Al-Mg-Si alloys. Acta Mater. 2016, 118, 296-305. [CrossRef]

17. Zhen, L.; FEI, W.D.; Kang, S.B.; Kim, H.W. Precipitation behaviour of Al-Mg-Si alloys with high silicon content. J. Mater. Sci. 1997, 7, 1895-1902. [CrossRef]

18. Pogatscher, S.; Antrekowitsch, H.; Leitner, H.; Ebner, T.; Uggowitzer, P.J. Mechanisms controlling the artificial aging of Al-Mg-Si Alloys. Acta Mater. 2011, 9, 3352-3363. [CrossRef]

19. Zakharov, V.V.; Fisenko, I.A. Some Principles of Alloying of Aluminum Alloys with Scandium and Zirconium in Ingot Production of Deformed Semiproducts. Metal Sci. Heat Treat. 2019, 3, 217-221. [CrossRef]

20. Zakharov, V.V. Combined alloying of aluminum alloys with scandium and zirconium. Metal Sci. Heat Treat. 2014, 3, 281-286. [CrossRef]

21. Röyset, J.; Ryum, N. Scandium in aluminium alloys. Int. Mater. Rev. 2005, 1, 19-44. [CrossRef]

22. Shvechkov, E.I.; Filatov, Y.A.; Zakharov, V.V. Mechanical and Life Properties of Sheets from Alloys of the Al-Mg-Sc System. Metal Sci. Heat Treat. 2017, 59, 454-462. [CrossRef]

23. Aryshenskii, E.V.; Hirsch, J.; Konovalov, S.V.; Prahl, U. Specific features of microstructural evolution during hot rolling of the as-cast magnesium-rich aluminum alloys with added transition metal elements. Metall. Mater. Trans. 2019, 12, 5782-5799. [CrossRef]

24. Peng, Z.W.; Li, J.F.; Sang, F.J.; Chen, Y.L.; Zhang, X.H.; Zheng, Z.Q.; Pan, Q.L. Structures and tensile properties of Sc-containing 1445 Al-Li alloy sheet. J. Alloys Compd. 2018, 747, 471-483. [CrossRef]

25. Rokhlin, L.L.; Bochvar, N.R.; Leonova, N.P.; Sukhanov, A.V. Effect of additional doping with scandium and scandium with zirconium on strength properties of the alloys of Al-Mg 2 Si system. Inorg. Mater. 2016, 15, 1467-1471. [CrossRef]

26. Babaniaris, S.; Ramajayam, M.; Jiang, L.; Langan, T.; Dorin, T. Tailored precipitation route for the effective utilisation of Sc and Zr in an Al-Mg-Si alloy. Materialia 2020, 10, 100656. [CrossRef]

27. Zupanič, F.; Steinacher, M.; Žist, S.; Bončina, T. Microstructure and Properties of a Novel Al-Mg-Si Alloy AA 6086. Metals 2021, 11,368. [CrossRef]

28. Dorin, T.; Ramajayam, M.; Babaniaris, S.; Jiang, L.; Langan, T.J. Precipitation sequence in Al-Mg-Si-Sc-Zr alloys during isochronal aging. Materialia 2019, 8, 100437. [CrossRef]

29. Kwon, E.P.; Do Woo, K.; Kim, S.H.; Kang, D.S.; Lee, K.J.; Jeon, J.Y. The effect of an addition of Sc and Zr on the precipitation behavior of AA6061 alloy. Met. Mater. Int. 2010, 5, 701-707. [CrossRef]

30. Babaniaris, S.; Ramajayam, M.; Jiang, L.; Langan, T.; Dorin, T. Developing an optimized homogenization process for Sc and Zr containing Al-Mg-Si alloys. Light Met. 2019, 1, 1445-1453.

31. Lityńska-Dobrzyńska, L. Precipitation of phases in Al-Mg-Si-Cu alloy with Sc and Zr additions during heat treatment. Solid State Phenom.-Trans. Tech. Publ. Ltd. 2007, 130, 163-166. [CrossRef] 
32. Vlach, M.; Smola, B.; Stulíková, I.; Očenášek, V. Microstructure and mechanical properties of the AA6082 aluminium alloy with small additions of Sc and Zr. Int. J. Mater. Res. 2009, 3, 420-423. [CrossRef]

33. GOST 9450-76. Measurements Microhardness by Diamond Instruments Indentation; Academy of Sciences of the USSR: Moscow, Russia, 1993.

34. Thermo-Calc Software. TCAL4 Al-Based Alloy Database, Version 4. Available online: https://www.engineering-eye.com/ THERMOCALC/details/db/pdf/thermo-calc/02/tcal40_extended_info.pdf (accessed on 1 May 2021).

35. Aryshenskii, E.; Hirsch, J.; Konovalov, S.; Aryshenskii, V.; Drits, A. Influence of mg content on texture development during hot plain-strain deformation of aluminum alloys. Metals 2021, 11, 865. [CrossRef]

36. Wang, F.; Qiu, D.; Liu, Z.L.; Taylor, J.A.; Easton, M.A.; Zhang, M.X. The grain refinement mechanism of cast aluminium by zirconium. Acta Mater. 2013, 61, 5636-5645. [CrossRef]

37. Yu, A.W.; Yang, C.G.; Wang, S.L.; Liu, F.C.; Zheng, Q. Effect of Sc, Zr grain refiner on the microstructure and mechanical properties of pure aluminum. Appl. Mech. Mater.-Trans. Tech. Publ. Ltd. 2014, 508, 16-21. [CrossRef]

38. Jiang, S.; Wang, R. Grain size-dependent $\mathrm{Mg} / \mathrm{Si}$ ratio effect on the microstructure and mechanical/electrical properties of Al-Mg-Si-Sc alloys. J. Mater. Sci. Technol. 2019, 7, 1354-1363. [CrossRef]

39. Yong, D.; Shuhong, L.; Baiyun, H.; Chang, Y.A.; Xie, F.Y.; Ying, Y.; Chen, S.L. Thermodynamic description of the Al-Fe-Mg-Mn-Si system and investigation of microstructure and microsegregation during directional solidification of an Al-Fe-Mg-Mn-Si alloy. Z. Für Met. 2005, 96, 1351-1362.

40. Litnska-Dobrzynska, L.; Dutkiewicz, J.; Maziarz, W.; Ochin, P. Structure and properties of Al-Mg-Si alloys with Zr and Sc additions produced by melt spinning and twin rolling casting techniques. Kov. Mater. 2010, 48, 9-15. [CrossRef]

41. Dorin, T.; Ramajayam, M.; Langan, T.J. Effects of $\mathrm{Mg}$, $\mathrm{Si}$, and $\mathrm{Cu}$ on the formation of the $\mathrm{Al}_{3} \mathrm{Sc}_{\mathrm{Al}} / \mathrm{Al}_{3} \mathrm{Zr}$ dispersoids. In Proceedings of the International Conference on Aluminium Alloys, Montréal, QC, Canada, 17-20 June 2018; Volume 16, pp. 1-11. Available online: http:/ / www.icaa-conference.net/ICAA16/Papers/Plenary\%20and\%20Early\%20Career/404566\%20Dorin_final.pdf (accessed on 1 May 2021).

42. Booth-Morrison, C.; Mao, Z.; Diaz, M.; Dunand, D.C.; Wolverton, C.; Seidman, D.N. Role of silicon in accelerating the nucleation of $\mathrm{Al}_{3}(\mathrm{Sc}, \mathrm{Zr}$ ) precipitates in dilute Al-Sc-Zr alloys. Acta Mater. 2012, 16, 4740-4752. [CrossRef]

43. Norman, A.F.; Prangnell, P.B.; McEwen, R.S. The solidification behaviour of dilute aluminium-scandium alloys. Acta Mater. 1998, 16, 5715-5732. [CrossRef]

44. Yashin, V.V.; Aryshensky, E.V.; Latushkin, I.A.; Stozharov, D.A. Study of kinetics of the supersaturated solid solution decomposition in alloys of the Al-Mg system with transition elements addition. Tsvetnye Met. 2020, 11, 77-84.

45. Nes, E.; Vatne, H.E. The 40 (111) Orientation Relationship in Recrystallisation/Die 40 (111) Orientierungsbeziehung bei der Rekristallisation. Z. Für Met. 1996, 87, 448-453. 